\begin{tabular}{l} 
2. To: (Receiving Organization) \\
Distribution \\
\hline $\begin{array}{l}\text { 5. Proj/Prog/Dept/Div.: } \\
\text { Long Length Equipment System }\end{array}$
\end{tabular}

8. Originator Remarks:

Review in support of Decision Planning

3. From: (Originating Organization)
TWRS Upgrade
$\begin{aligned} & \text { 6. Design Authority/Design Agent/Cog. Engr.: } \\ & \text { George Janicek }\end{aligned}$

6. Design Authority/Design
George Janicek
4. Related EDT No.:
none
7. Purchase Order No.:
none
9.: Equip./Component No.:

(see text)

10. System/Bldg./Facility:

200 General

12. Major Assm. Dwg. No.

H-2-78870

13. Permit/Permit Application No.:

(see text)

14. Required Response Date:

$6 / 17 / 99$

\begin{tabular}{c|c|c|c|}
$(F)$ & $(G)$ & $(H)$ & $(I)$ \\
\hline $\begin{array}{c}\text { Approval } \\
\text { nator } \\
\text { nator }\end{array}$ & $\begin{array}{c}\text { Reason Trans- } \\
\text { mittal }\end{array}$ & $\begin{array}{c}\text { Origi- } \\
\text { nator } \\
\text { Dispo- } \\
\text { stion }\end{array}$ & $\begin{array}{c}\text { Receiv- } \\
\text { er } \\
\text { Dispo- } \\
\text { sition }\end{array}$ \\
\hline
\end{tabular}

15.

DATA TRANSMITTED

(A)

No.

(B) Document/Drawing No.

(C) Sheet
No.

(E) Title or Description of Data Transmilted

1

ANF -

HWI 4329

pro.602.19.

16.

\begin{tabular}{|l|l|}
\hline all & 0 \\
\hline & \\
\hline & \\
\hline & \\
\hline & \\
\hline
\end{tabular}

AGA FOR LONG LENGTH

CONTAMINATED EQUIPMENT

REMOVAL SYSTEM STORAGE

\begin{tabular}{|c|l|}
\hline Approval Designator $(F)$ & \\
\hline $\begin{array}{c}\text { E, S, }, D, D R \text { N/A } \\
\text { (See WHC-CM-3-5, } \\
\text { Sec. 12.7) }\end{array}$ & $\begin{array}{l}\text { 1. Approval } \\
\text { 2. Release } \\
\text { 3. Information }\end{array}$ \\
\hline
\end{tabular}

17.

Reason for Transmittal (G)

KEY

Disposition (H) \& (I)

\begin{tabular}{l|ll} 
4. Review & 1. Approved & 4. Reviewed no/comment \\
5. Post-Revlew & 2. Approved w/comment & 5. Revlewed w/comment \\
6. Dist. (Recelpt Acknow. Required) & 3. Disapproved w/comment & 6. Receipt acknowledged
\end{tabular}

SIGNATURE/DISTRIBUTION

(See Approval Designator for required signatures)

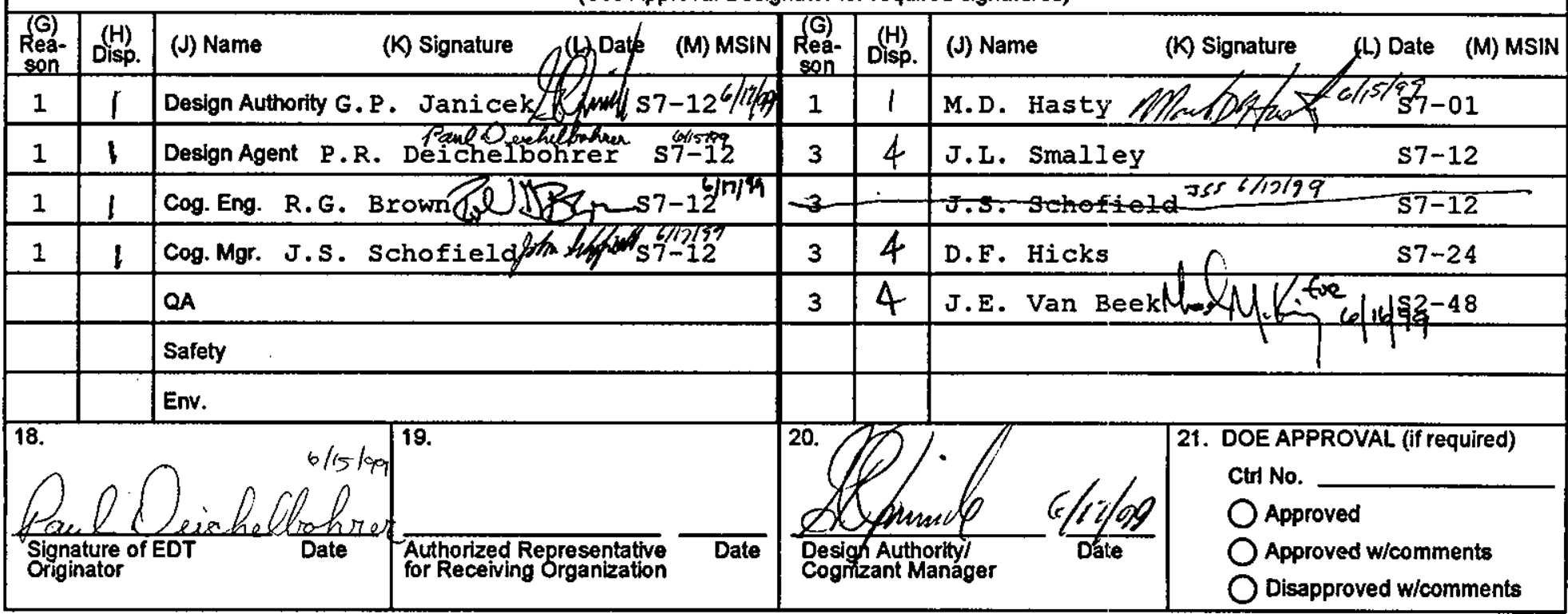




\title{
ALTERNATIVES GENERATION ANALYSIS LONG LENGTH CONTAMINATED EQUIPMENT REMOVAL SYSTEM STORAGE
}

\author{
R.M. Boger \\ Prepared by Lockheed Martin Hanford Corporation \\ Richland, WA 99352 \\ U.S. Department of Energy Contract DE-AC06-96RL13200 \\ EDT/ECN: 619147 \\ Org Code: UH 310000 \\ B\&R Code: EW3120074 \\ UC: 2030 \\ Charge Code: 102315 EI0 \\ Total Pages: 56
}

Key Words:

long length contaminated equipment, flexible receiver, sprung frame, warehouse, AGA

Abstract:

The long length contaminated equipment was designed and built to aid in the remote removal and transport of highly radioactive, contaminated equipment from various locations in the tank farms to disposal. The equipment has been stored in an open lay-down yard area, exposed to the elements for the past year and a half. The possible alternatives available to provide shelter for the equipment are investigated.

TRADEMARK DISCLAIMER. Reference herein to any specific commercial product, process, or service by trade name, trademark, manufacturer, or otherwise, does not necessarily constitute or imply its endorsement, recommendation, or favoring by the United States Government or any agency thereof or its contractors or subcontractors.

Printed in the United States of America. To obtain copies of this document, contact: Document Control Services, P.O. Box 950, Mailstop H6-08, Richland WA 99352, Phone (509) 372-2420; Fax (509) 376-4989.
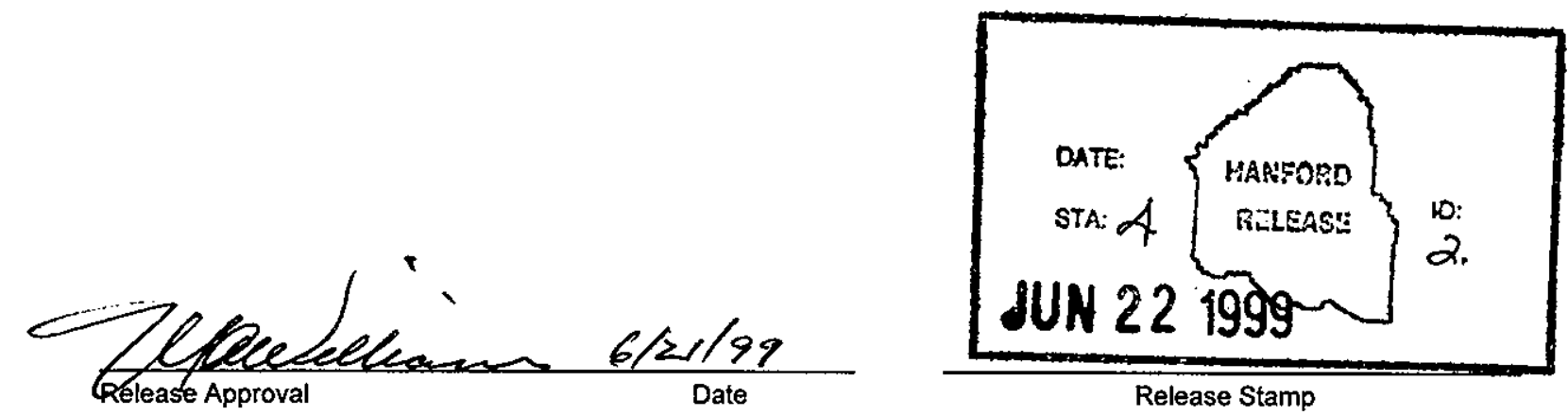

Release Stamp 


\section{ILCERS Storage}

Decision Board
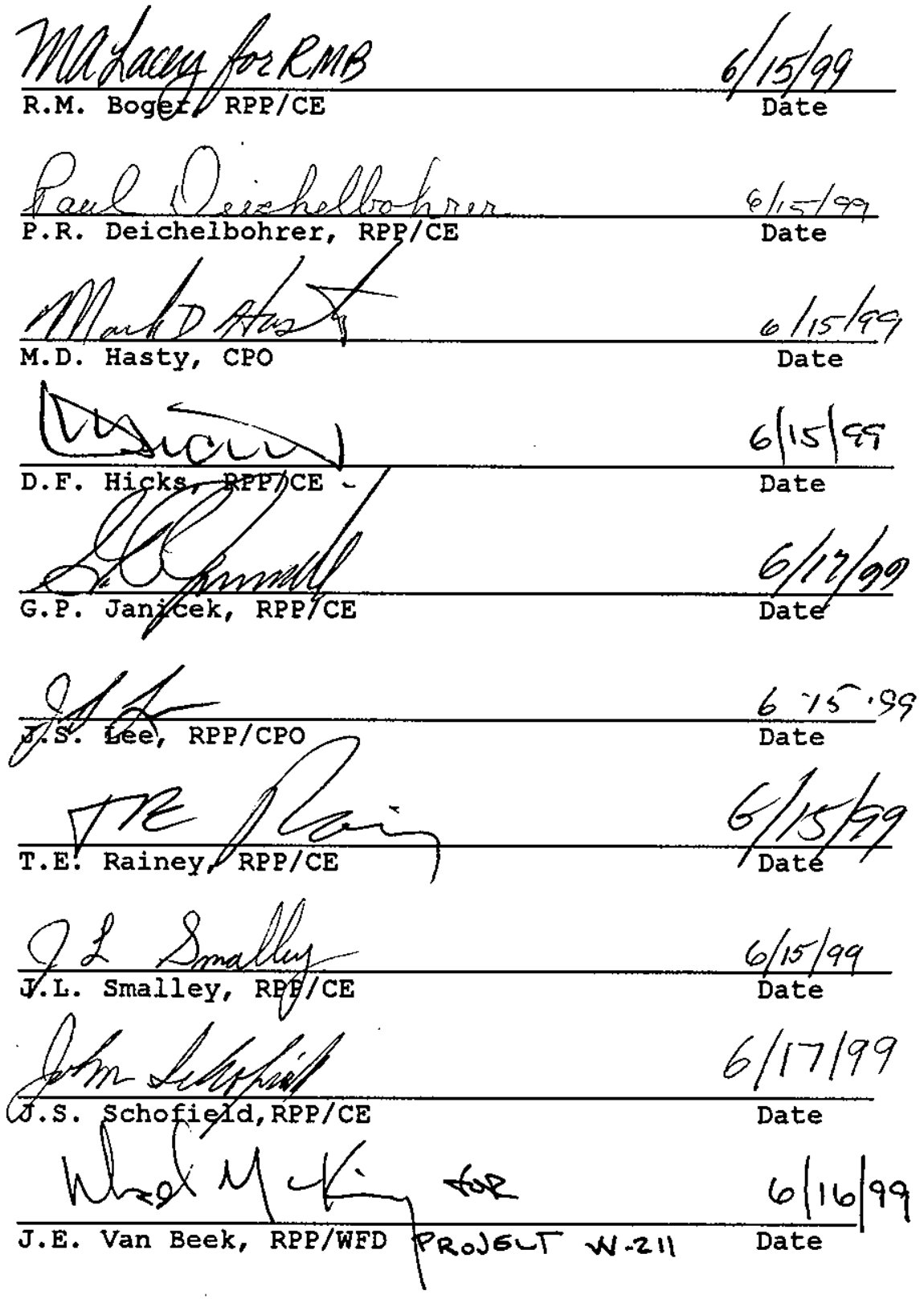


\title{
ALTERATIVES GENERATION AND ANALYSIS REPORT
}

\author{
STORAGE AND MAINTENANCE ACTIVITIES \\ OF CHARACTERIZATION LONG LENGTH \\ CONTAMINATED EQUIPMENT \\ REMOVAL SYSTEM
}

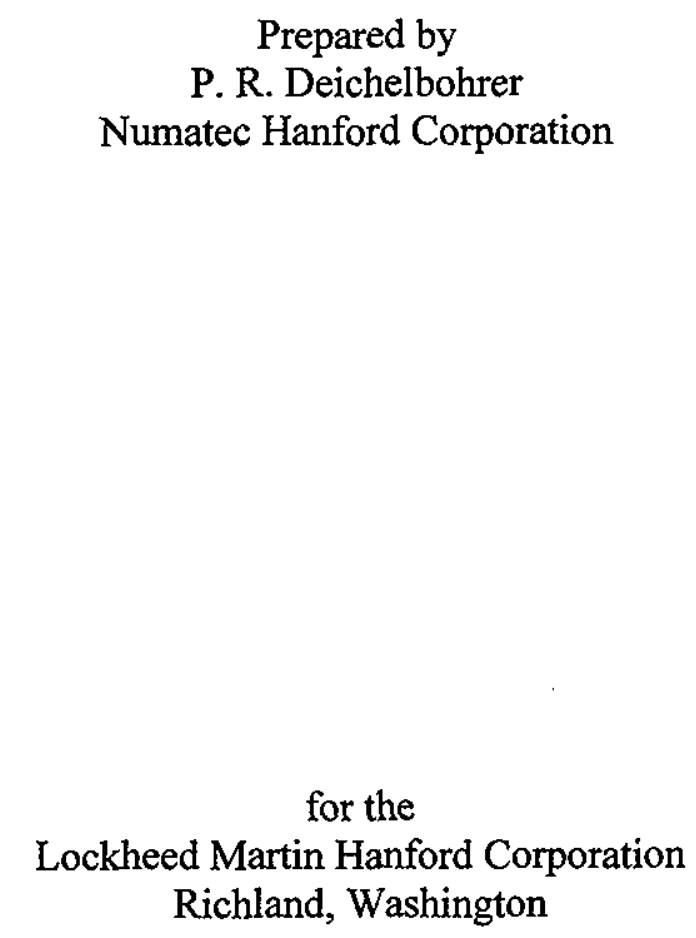




\section{CONTENTS}

1.0 DECISION ANALYSIS SUMMARY

1.1 STATEMENT OF THE ISSUE.

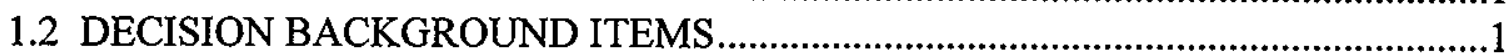

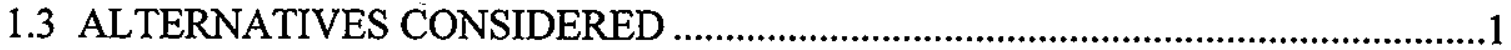

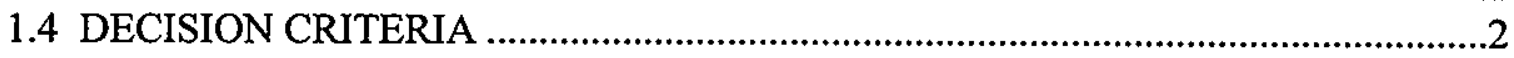

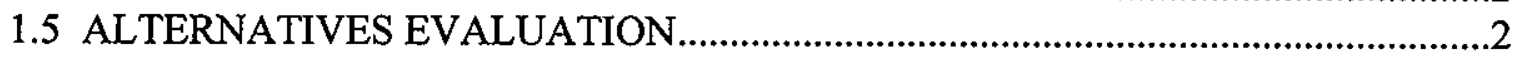

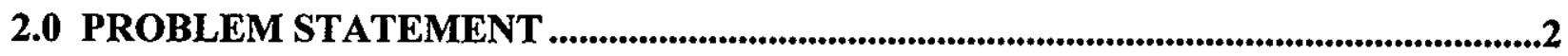

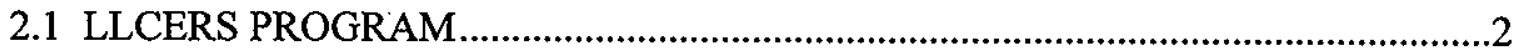

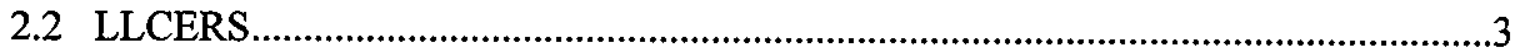

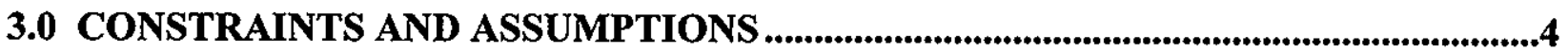

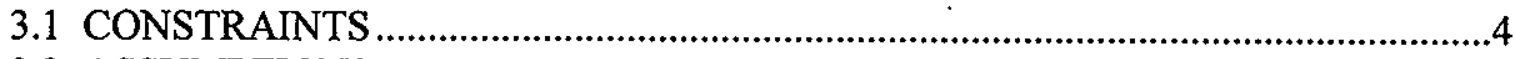

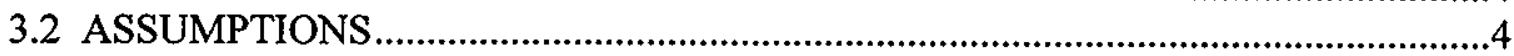

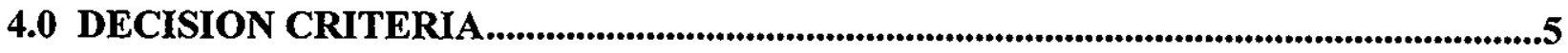

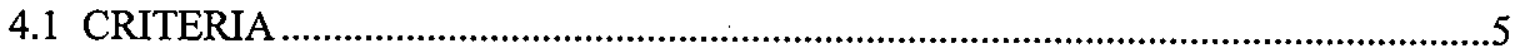

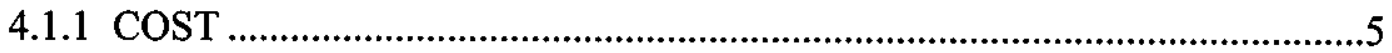

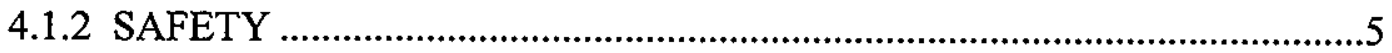

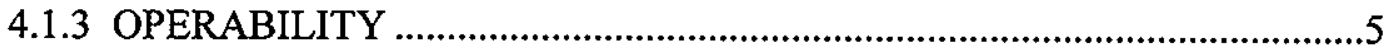

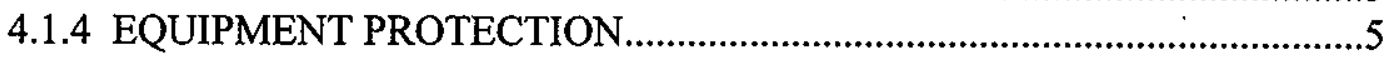

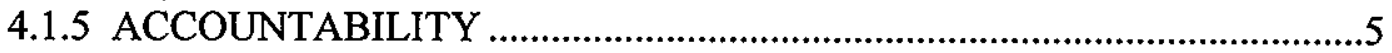

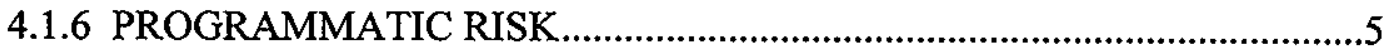

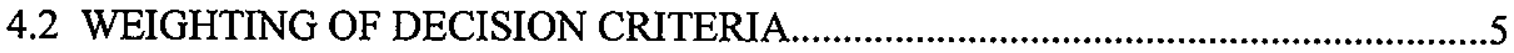

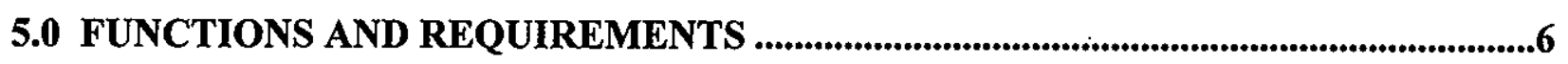

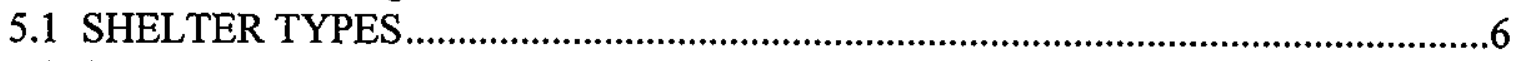

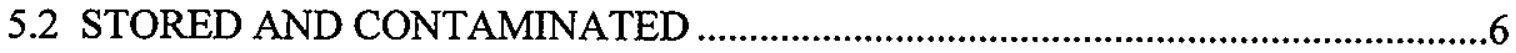

6.0 ALTERNATIVES DESCRIPTION

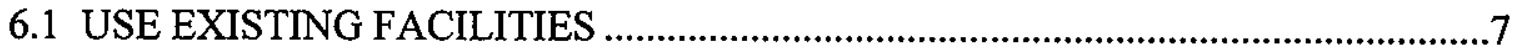

6.1.1 ALTERNATIVE 1 - BUILDING 337/300 HIGH BAY …….........................

6.1.2 ALTERNATIVE 2 - BUILDING 335/300 MAINTENANCE SHOP............7

6.1.3 ALTERNATIVE 3 - BUILDING 167 AT WNP-1 ..........................................

6.1.4 ALTERNATIVE 4 - BUILDING 275-EA/200 OLD PUREX WAREHOUSE ...8

Page ii 


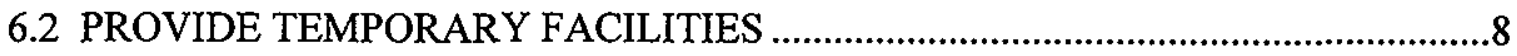

6.2.1 ALTERNATIVE 5 - PURCHASE PORTABLE FABRIC

STRUCTURE ...............................................................................

6.2.2 ALTERNATIVE 6 - LEASE PORTABLE FABRIC STRUCTURE...............9

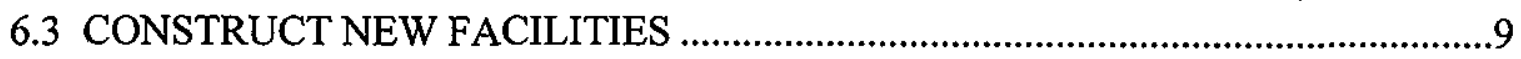

6.3.1 ALTERNATIVE 7 - CONSTRUCT POLE BUILDING …............................9

6.3.2 ALTERNATIVE 8 - CONSTRUCT METAL BUILDING............................9

6.4 ALTERNATIVE 9 - MAINTAIN AND STORE IN PLACE ……...........................10

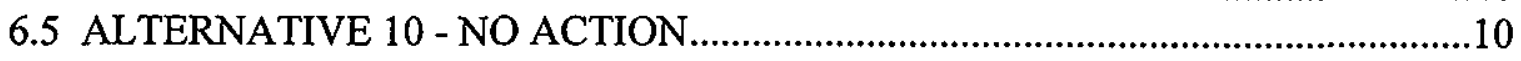

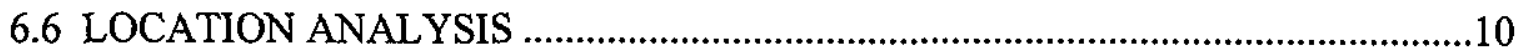

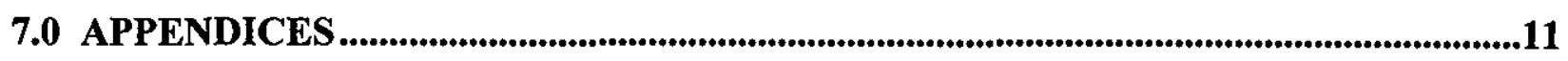

A-1 - "Determination of Structure Type and Location for a Storage Shelter for the Long-Length Contaminated Equipment (LLCE)" Engineering Study,

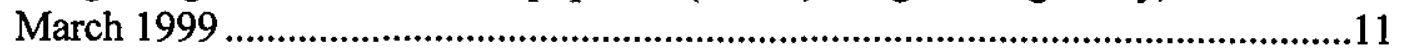

A-2 - "Determination of Structure Type and Location for a Storage Shelter for the Long-Length Contaminated Equipment (LLCE)" Final Report, May 1999...........11

B - Decision Plan .............................................................................................................11

C - Meeting Minutes ............................................................................................................11

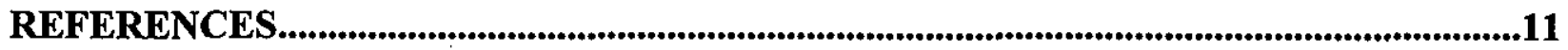

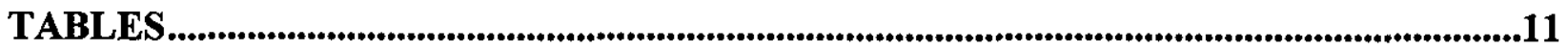


HNF-4329, Rev. 0

\author{
ALTERATIVES GENERATION AND ANALYSIS REPORT \\ STORAGE AND MAINTENANCE ACTIVITIES \\ OF CHARACTERIZATION LONG LENGTH \\ CONTAMINATED EQUIPMENT \\ REMOVAL SYSTEM
}

\title{
1.0 DECISION ANALYSIS SUMMARY
}

\subsection{STATEMENT OF THE ISSUE}

Major pieces of Characterization sampling equipment are currently stored outdoors. This includes the Long Length Contaminated Equipment receiver trailer and transportation trailer. A decision is required to determine the preferred alternative for facilities to store and maintain this equipment.

\subsection{DECISION BACKGROUND ITEMS}

The Long Length Contaminated Equipment Removal System (LLCERS) consists of many tools, mechanisms, and controllers currently stored in various locations. Much of this equipment should be protected from the elements while being stored. Some of the LLCERS equipment should be protected with some kind of roof cover. This decision analysis is to determine the best alternative for weather protection for the large equipment requiring a cover. Additional details are included in Sections 2.0 and 5.0. Key assumptions used in this analysis are detailed in Section 3.2.

\subsection{ALTERNATIVES CONSIDERED}

These alternatives were directed into two decisions: The first decision was to determine the kind of facility for storage. With the determination that some new facility would be needed, alternatives for locations of the facility were considered.

The following alternatives were considered. A detailed description of the alternatives is included in Section 6.0:

- use building $337 / 300$ high bay

- use building 335/300 maintenance shop

- use building 167 at WNP-1

- use building 275-EA/200E, old PUREX warehouse

- procure temporary facilities

- construct new facilities

- have separate facilities for non-smearable and non-contaminated 
HNF-4329, Rev. 0

- maintain and store in place
- take no action

\subsection{DECISION CRITERIA}

A decision criterion is a factor used to select a preferred alternative. The following relevant decision criteria were chosen for the conduct of the decision analysis process. A detailed description of the criteria is included in Section 4.0.

- Cost

- Safety

- Operability

- Equipment Protection

- Accountability

- Programmatic Risk

\subsection{ALTERNATIVES EVALUATION}

A summary of the analysis results for each of the alternatives is presented in this section. Additional information is contained in Section 6.0. The performance scores for each alternative are summarized in Tables 1,2, and 3. Since some of the alternatives entailed erecting a new structure and some used existing structures, the evaluation of where to locate any new structure was going to be performed only if one of the new structures was the preferred alternative. This also made the initial evaluation less complicated. Three alternatives did not pass the initial screening and were not evaluated.

During the initial evaluation Alternatives 5, 7, and 8 (fabric structure, pole building, and metal building) received the same score, which tied them for being the preferred alternative. These three alternatives were further evaluated against each other. Three decision criteria (Operability, Equipment Protection, and Accountability) were not used in the evaluation because each alternative was considered to be equal for those criteria. Table 2 summarizes this evaluation.

The evaluation of the location of the new structure is summarized in Table 3. Two decision criteria (Equipment Protection and Programmatic Risk) were not used in the evaluation because each alternative is considered to be equal for those criteria.

\subsection{PROBLEM STATEMENT}

\subsection{LLCERS PROGRAM}

Over the next ten years or so the Hanford underground waste tanks are scheduled to be retired. As part of that effort, the long length equipment inserted into the tanks (on the order of 1300 pieces) (Grams 1998, Roach 1995), such as thermocouple trees, pumps, level gages, etc., will have to be removed. These pieces of equipment are highly contaminated, and removing/disposing of them requires special procedures and equipment. 
This equipment, known collectively as the Long Length Contaminated Equipment Removal System (LLCERS) Equipment, consists of approximately 150 individual tools/mechanisms/controllers stored at four locations in the 200 Areas. A complete list of these items can be found in Appendix D (Compilation of Long length Contaminated Equipment System Equipment). Along with a description of the equipment, its location and size are given in the table. In addition, comments as to recommended handling methods, storage urgency, and ownership can be found.

Ownership refers to the organization/project "tasked" with the planned LLCE removal effort. Some of the items are owned by Project W-211, which has the overall responsibility of providing feed material to the forthcoming vitrification campaign.

This Alternatives Generation Analysis (AGA) does not concern itself with storage of Project W-211 items. They are included in Appendix D for reference only.

Other LLCE removal efforts will be within the responsibility of the River Protection Project/Characterization Project Operations (RPP/CPO). (The River Protection Project [RPP] was formerly known as the Tank Waste Remediation System [TWRS].) Besides the equipment assigned to RPP/CPO, all of the items associated with the now-completed Project 320 are assumed to be the responsibility of this AGA. In addition, a number of replacement/consumable items (used by Project W-211) will have to be procured by RPP/CPO some time in the future. Consequently, this AGA will arrange for storage space to be in-place when these items are eventually purchased. The items for which storage is required by this AGA are tabulated in Table 4.

It is expected that RPP/CPO will support LLCE removal efforts site-wide. In support of vitrification feed material, RPP/CPO expects to provide Project W-211 with receiver/transportation trailers, high-pressure water washers, and other equipment/services as needed.

\subsection{LLCERS}

Long Length Contaminated Equipment Removal System (LLCERS) Equipment is intended to remotely remove radioactive, contaminated equipment from underground storage tanks. The LLCERS is designed around the concept of a flexible receiver, which is essentially a heavy-duty (Hypalon(B) bag into which the long length in-tank equipment is pulled as it comes out of the tank. Once out of the tank and in the flexible receiver, it is placed in a trailer-mounted "strong back" receiver trailer (Item 43, Table 4) which lowers the LLCE piece to the horizontal position. Another trailer, transportation trailer, (Item 44, Table 4) then inserts the bagged LLCE component into a burial container. 
The entire LLCERS is completely remotely operated and automatic. Besides the bagging and handling equipment, the LLCERS includes a large quantity of specialty tooling, which performs functions such as the following:

- assaying the nature of the LLCE component's radioactive contamination

- $\quad$ spray washing equipment

- mating to the various sized tank risers

- storage containers for the used (i.e., contaminated) staging equipment

- remotely viewing equipment

- computer controlling equipment.

Appendix D lists all of the LLCERS equipment. The location of the lay-down areas for each of the LLCERS components is also listed.

The LLCERS receiver trailer and transportation trailer have been stored outside for the past two years. If no action is taken to protect the equipment from prolonged exposure to the elements (wind, rain, snow, sunlight), the more vulnerable components such as electrical wiring, hoses, gaskets, and tires will deteriorate. This condition will require a significant quantity of component replacement and potential re-testing of the LLCERS.

\subsection{CONSTRAINTS AND ASSUMPTIONS}

\subsection{CONSTRAINTS}

There are no constraints identified for the purposes of this AGA.

\subsection{ASSUMPTIONS}

It is assumed that

- the storage effort of the LLCERS components can be financed with expense funds or that expense funds can be reprogrammed to capital funds.

- the LLCERS will be used on a repetitive basis in tank farms as in-tank equipment is to be retrieved.

- the next assignment for the LLCERS equipment will be Project W-211.

- Project W-211 will commence in approximately one year.

- all maintenance and operating procedures will be in place by the initiation of Project W-211. Engineering/design of the LLCERS is (essentially) complete.

- only a small portion of the equipment will be contaminated after use. It is assumed that the contamination will be non-smearable. 
HNF-4329, Rev. 0

\subsection{DECISION CRITERIA}

\subsection{CRITERIA}

A decision criterion is a factor used to select a preferred alternative. The following relevant decision criteria were chosen.

\subsubsection{COST}

The cost of the alternative is the total cost with the assumption that the life cycle is complete within ten years.

\subsubsection{SAFETY}

Impact on the health and safety of Hanford Site Workers and the off-site population from radiological, toxicological, industrial, and environmental hazards associated with work site activities - Controlling radiation exposure to employees at levels that are as low as reasonably achievable (ALARA) shall be a primary goal.

\subsubsection{OPERABILITY}

"Ease of Use" operability measures to consider include preparation of equipment for first deployment, preventive maintenance (before deployment and after deployment), storage of contaminated equipment, and availability of equipment for training.

\subsubsection{EQUIPMENT PROTECTION}

Impact on the condition of the equipment while in storage, including the amount of degradation of parts and systems

\subsubsection{ACCOUNTABILITY}

Physical security of all equipment

\subsubsection{PROGRAMMATIC RISK}

Alternatives are evaluated based on the ability to meet current and potential future requirements for removal of long length contaminated equipment from tanks.

\subsection{WEIGHTING OF DECISION CRITERIA}

The decision criteria described above are weighted according to their relative degree of importance. Assigning numerical values quantifies the criteria and reduces the effect of evaluator bias on the analysis. The sum of the weights of all of the criteria is equal to 1.00 . The Decision Plan describes the method of judging the performance level. The performance of each alternative is estimated with respect to each criterion in Section 6 of this analysis. The performance level is judged as poor, average, or good with corresponding scores of 1,2 , or 3 , respectively. Among the alternatives compared, at least one alternative must receive a score of 1 and another a 3 if there are differences between the alternatives. If there were no differences among the alternatives for a specific category, that category would be deemed "not applicable" for purposes of evaluating differences among the alternatives. The weighted score is the product 
of each weighted criterion and the corresponding performance level score. The total score of each alternative is the sum of the weighted scores. The analysis of the alternatives performed with numerical weighting and performance levels is documented in tabular form in Tables 1,2, and 3.

Weighting factors for each of the criteria have been determined by the Decision Maker with the support of the Decision Support Board.

\subsection{FUNCTIONS AND REQUIREMENTS}

\subsection{SHELTER TYPES}

In Table 4 the clearance dimensions (length, width, height) are given for the LLCERS components that are to be stored by RPP/CPO. Additionally, the required area is given, which is the clearance area plus a foot or so of space around the equipment for access. Other information, such as the recommended type of shelter, handling method, and relative cost estimate is also given.

Most of the LLCERS equipment does not need much more shelter than a $\operatorname{tarp}(7000 \mathrm{sq} f \mathrm{ft}$ ). However, a smaller amount $(5000 \mathrm{sq} \mathrm{ft})$ requires at least roof cover. This area includes access to those items that have to be maintained/exercised while in storage.

Components that have clearance dimensions less than approximately four feet can be stored in Conex boxes. In Table 4 about $1700 \mathrm{sq} \mathrm{ft}$ of area is identified as Conex-box storage, which equates to three Conex boxes. The rest of the LLCERS equipment ( $1200 \mathrm{sq} \mathrm{ft}$ ) is intended for outdoor use/storage and can continue to be stored in a lay-down yard. The total required square footage in Table 4 is 15,000 .

It should be noted that the total "clearance" area for all of the LLCER equipment (Appendix D) is approximately $22,000 \mathrm{sq} \mathrm{ft}$.

\subsection{STORED AND CONTAMINATED}

Generally, equipment that has been used in a tank farm is considered to be potentially contaminated. However, great effort is normally expended in preventing contamination of most of the LLCE components. Components such as

- receiving/transportation trailers,

- work platforms,

- lift bail extensions,

- equipment used in pits,

- transfer chutes/troughs,

- flexible receiver applicators,

- containers for platforms/receiver applicators,

- $\quad$ and high pressure water washers 
HNF-4329, Rev. 0

would not be expected to be contaminated during LLCERS operation.

The rest of the items either will not enter tank farms and, thus, not be contaminated (e.g., control trailers, conex boxes) or will be buried with the removed LLCERS (e.g., burial containers, tank insertions).

Experience in using the first generation of the LLCERS (Project W-320) has shown that equipment items could be "free released" after deployment in tank farms. The only exception was the flexible receiver that is being stored in boxes at a radiation buffer area (RBA) (see Appendix D). In Appendix D components that could, potentially, become classified as "regulated/non-smearable" are identified.

\subsection{ALTERNATIVES DESCRIPTION}

The purpose of this Alternatives Generation Analysis is to investigate the possible alternatives available to provide a shelter for the LLCERS equipment to minimize damage from the weather.

\subsection{USE EXISTING FACILITIES}

\subsubsection{ALTERNATIVE 1 - BUILDING 337/300 HIGH BAY}

The 337 High Bay is in the 300 Area about 20 miles from tank farms. Most of its floor space (about $10,000 \mathrm{sq} \mathrm{ft}$ ) is currently available for rent. Some sodium stabilization activity is continuing in the back part of the building, but this activity would not impact storage of the LLCERS equipment. The doorway height is 20 feet. The charge-out rate is $\$ 36 / \mathrm{sq} \mathrm{ft} / \mathrm{yr}$. Radioactively regulated equipment/material is not allowed.

During the decision analysis meeting, it was observed that the access to this building (driveway) is too restricted for movement of the receiver trailer and the transportation trailer.

\subsubsection{ALTERNATIVE 2 - BUILDING 335/300 MAINTENANCE SHOP}

The 335 Maintenance Shop is across the street from the 335 building, i.e., approximately 20 miles from tank farms. Currently the building is empty. It has $7200 \mathrm{sq} \mathrm{ft}$ plus an office area. However, it has no fire protection. The charge-out rate is $\$ 36 / \mathrm{sq} \mathrm{ft} / \mathrm{yr}$. The doorway is $20 \mathrm{ft} \mathrm{high}$. Radioactively regulated equipment/material is not allowed.

During the decision analysis meeting, it was observed that the access to this building (driveway) is too restricted for movement of the receiver trailer and the transportation trailer.

\subsubsection{ALTERNATIVE 3 - BUILDING 167 AT WNP-1}

WNP-1 has a large number of buildings (estimate 50 ) to be leased--not all of which are warehouses. Most of the buildings that would be suitable for LLCERS storage have been leased or are being used. The 167 building, however, would be suitable for LLCERS equipment, and will be available in 30 days. It has $7200 \mathrm{sq} \mathrm{ft}$ of floor space and its doorway height is $13 \mathrm{ft}$. It 
rents for $\$ 2.50 / \mathrm{sq} \mathrm{ft} / \mathrm{yr}$. It does not have any fire protection. Radioactively regulated equipment/material is not allowed.

\subsubsection{ALTERNATIVE 4 - BUILDING 275-EA/200 OLD PUREX WAREHOUSE}

The 275-EA warehouse was built before/during PUREX construction to store building material and equipment. According to some points of view, the building was supposed to be torn down after.PUREX was complete, but it was used to store jumpers and chemicals during the operational history of PUREX. It is an L-shaped building with a kind of courtyard/parking lot in the space between the legs of the $L$.

The building is being prepared to be torn down, but structurally it is still sound (roof tight, etc.), but all utilities have been disconnected, especially fire protection. Estimates for re-installing fire protection range up to $\$ 500 \mathrm{k}$.

275-EA has $35,000 \mathrm{sq} \mathrm{ft}$ of floor space, but the ceiling is rather low. The door opening is $9 \mathrm{ft}$ $11 \mathrm{in}$. There is no ramp access--the building is accessed by means of a loading dock that runs the length of both legs of the $\mathrm{L}$. There is a porch over the loading dock. There appears to be plenty of room in the courtyard to build a ramp if it were necessary.

The current owners would like to give the building away. Consequently, they have no impositions as to use with contaminated material/equipment.

During the decision analysis meeting, it was observed that this building has insufficient height for the receiver and transportation trailers.

\subsection{PROVIDE TEMPORARY FACILITIES}

Fluor Daniel Northwest, Inc. produced a report (Appendix A) on concepts of erecting temporary facilities for the LLCERS equipment. It covers some erection details, site preparation, and costs for tent-type covers and other temporary buildings. Details relating such structures to the Uniform Building Code are also included. The estimates are based on a 7200 -sq-ft structure, which would be sufficient to support the storage requirements called out in Table 4.

\subsubsection{ALTERNATIVE 5 - PURCHASE PORTABLE FABRIC STRUCTURE}

Appendix A recommends a sprung-arched frame support and membrane system as the most versatile shelter type. It represents maximum flexibility and could be located, relocated, or removed as necessary with little effort.

Rough cost estimates were obtained from vendors. For an enclosed structure, the study found an estimate of $\$ 13$ to $\$ 17$ per sq $\mathrm{ft}$ and $\$ 12$ per sq $\mathrm{ft}$ of a roof only. Prices vary somewhat between steel and aluminum frame arch. These estimates are based on a 7200-sq-foot structure.

LLCERS needs $5000 \mathrm{sq} \mathrm{ft}$, as shown in Table 4, which could be provided for between $\$ 60 \mathrm{k}$ and $\$ 85 \mathrm{k}$. It is assumed that the structure would be purchased and built, as a commercial building would be outside the Hanford site, by the vendor. Foundation costs are not included in the above 
estimates, but are included in Paragraph 6.6.

It is also assumed that non-smearable equipment could be stored in a newly-constructed shelter if necessary permitting were acquired.

\subsubsection{ALTERNATIVE 6 - LEASE PORTABLE FABRIC STRUCTURE}

Appendix A includes costs for leasing a sprung-arched frame support and membrane system. Based on the assumed life cycle of ten years for the LLCERS (Paragraph 4.1.1), the rental can be seen to be $\$ 2000$ to $\$ 2500$ per month for a 7200 -sq-foot shelter, which amounts to $\$ 0.28$ to $\$ 0.35 / \mathrm{sq} \mathrm{ft} /$ month, depending upon construction material and whether the shelter has walls. Considering that RPP/CPO requires $5000 \mathrm{sq} f$ for 120 months, the rented shelter would cost between $\$ 170 \mathrm{k}$ and $\$ 200 \mathrm{k}$.

\subsection{CONSTRUCT NEW FACILITIES}

Appendix A considers two types of semi-permanent shelters:

- a pole-and-wood-frame structure with metal roof and siding;

- a rigid-fame, steel structure with corrugated metal walls and roof.

\subsubsection{ALTERNATIVE 7 - CONSTRUCT POLE BUILDING}

Rough cost estimates were obtained from vendors for a pole-type shelter, assuming that the structure would be purchased and built as any commercial building would be outside the Hanford site by the vendor. Based upon a $60 \times 120$-ft building, the cost is between $\$ 4$ and $\$ 7.60 / \mathrm{sq} \mathrm{ft}$, depending on whether the shelter needs walls. For the $5000 \mathrm{sq} \mathrm{ft} \mathrm{required} \mathrm{in} \mathrm{Table} \mathrm{4,} \mathrm{this} \mathrm{type} \mathrm{of}$ construction is expected to cost $\$ 20 \mathrm{k}$ to $\$ 38 \mathrm{k}$.

It assumed that non-smearable equipment could be stored in a newly constructed shelter if appropriate/necessary permitting were acquired.

In addition, certain site improvements may be necessary, based upon existing site conditions, considering the size, weight, and maneuverability of the LLCERS trailers.

During the decision analysis meeting, it was observed that pole buildings are a permanent type structure and, thus, less versatile than some other types of shelter.

\subsubsection{ALTERNATIVE 8 - CONSTRUCT METAL BUILDING}

As can be seen in Appendix A, cost estimates were obtained from a vendor for a metal building, assuming that the shelter would be purchased and built as any commercial building would be outside the Hanford site by the vendor.

The cost per square foot, given in Appendix A, is between $\$ 11$ and $\$ 16$, depending upon the need for walls. For the $5000 \mathrm{sq} \mathrm{ft}$ required by Table 4 , the steel structure would be expected to cost between $\$ 55 \mathrm{k}$ and $\$ 80 \mathrm{k}$. 
It assumed that non-smearable equipment could be stored in a newly constructed shelter if appropriate/necessary permitting were acquired.

In addition, certain site improvements may be necessary, based upon existing site conditions, considering the size, weight, and maneuverability of the LLCERS trailers.

During the decision analysis, meeting, it was observed that a metal building is essentially a relocatable type of structure and, thus, it would be more versatile than a pole building.

\subsection{ALTERNATIVE 9 - MAINTAIN AND STORE IN PLACE}

Most of the LLCERS equipment is designed for out-of-doors use and is constructed to be kept outside. For all of the LLCERS, the effect of weather deterioration could be minimized if shelter could be provided.

Outdoor storage of those components designed for outdoor storage would be an acceptable alternative to constructing a building or using an old building. However, this approach would require that regular preventive maintenance (PM) be performed on the equipment. At the present time, the cost of this alternative is difficult to estimate since PM procedures are not available for the LLCERS.

\subsection{ALTERNATIVE 10 - NO ACTION}

The LLCERS has been stored in several open, lay-down areas, exposed to the elements for the past two years.

If no action is taken to protect the equipment from prolonged exposure to the elements (wind, rain, snow, sunlight), the more vulnerable components such as electrical wiring, hoses, gaskets, hydraulic cylinders, and tires will deteriorate. This condition will require a significant quantity of component replacement and potential re-testing of the LLCERS.

\subsection{LOCATION ANALYSIS}

In Appendix A three locations are suggested for erection of a temporary/permanent shelter. Two of the three are at the Cold Test Facility (between 200E and 200W areas, across Route 3 from the fire station) and the third is just west of it.

Because the receiving trailer and transportation trailer are so large and difficult to maneuver, the Appendix A report includes a certain amount of road improvements for moving the trailers. In addition, the surface upon which the trailers will be set will have to be specially prepared with crushed stone to support them. The cost of the roadwork including a crushed-stone trailer pad (see Appendix $\mathrm{A}$ ) is between $\$ 100 \mathrm{k}$ and $\$ 180 \mathrm{k}$, depending upon which location near the Cold Test Facility is chosen.

Another location to be considered is the lay-down yard north of 2704HV. Currently, the area is largely vacant, and ground improvements are already in place. Site improvement costs 
approaching $\$ 100 \mathrm{k}$ to $\$ 180 \mathrm{k}$ could be avoided in the $2704 \mathrm{HV}$.

Table 2 (Decision Criteria Matrix) provides a list of shelter types, the shelter providers, and a rough cost estimate for each. The costs for the constructed facilities are primarily based on Appendix A.

\subsection{APPENDICES}

A-1 - "Determination of Structure Type and Location for a Storage Shelter for the Long-Length Contaminated Equipment (LLCE)" Engineering Study, March 1999

A-2 - "Determination of Structure Type and Location for a Storage Shelter for the Long-Length Contaminated Equipment (LLCE)" Final Report, May 1999

B - Decision Plan

C - Meeting Minutes

D - Compilation of Long Length Contaminated Equipment System Equipment

\section{REFERENCES}

Grams, W. H., 1998, "Unreviewed Safety Question Screening, TF-98-0544, "Long Length Equipment Removal Using the Flexible Receiver," dated June 2, 1998.

Roach, H. L., ICF-KH, Letter to P. A. Titzler, WHC, "FY2000 Potential LLCE Retrievals and All LLCE Sorted by Container Size," ETS-W-95-2322, dated August 22, 1995.

\section{TABLES}

Table 1 - Decision Criteria Matrix for LLCERS Storage Facility

Table 2 - Decision Criteria Matrix for LLCERS New Storage Building

Table 3 - Decision Criteria Matrix for LLCERS Storage Facility Location

Table 4 - RPP Long Length Contaminated Equipment System Equipment 


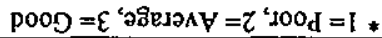

\begin{tabular}{|c|c|c|c|c|c|c|c|c|c|c|c|c|c|c|c|c|c|c|c|c|c|}
\hline Or' I & & $S S \mathfrak{I}$ & & $\$ 6 \%$ & & $\$ 6 \tau$ & & $\varsigma 97 z$ & & 567 & & $00^{\circ} 0$ & $V / N$ & $0 \nabla^{\prime} z$ & & $00^{\circ} 0$ & $V / N$ & 000 & $\nabla / N$ & $00^{\circ} x$ & โשฺOL \\
\hline oro & I & $0 I^{\circ} 0$ & $\mathbf{i}$ & $0 \varepsilon^{0}$ & $\varepsilon$ & $0 \varepsilon 0$ & $\varepsilon$ & $0 \varepsilon 0$ & $\varepsilon$ & $0 \varepsilon 0$ & $\varepsilon$ & $00^{\circ} 0$ & & $0 \tau 0$ & $z$ & $00^{\circ} 0$ & & $00^{\circ} 0$ & & $0 \mathrm{I}^{\circ} 0$ & 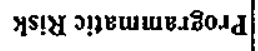 \\
\hline$s 0^{\circ} 0$ & I & so'o & I & sio & $\varepsilon$ & sio & $\varepsilon$ & SIO & $\varepsilon$ & sio & $\varepsilon$ & $00^{\prime} 0$ & & sio & $\varepsilon$ & 000 & & $00^{\prime} 0$ & & $50^{\circ} 0$ & S4!!!q \\
\hline $0 \varepsilon^{\circ} 0$ & I & $0 \varepsilon 0$ & I & 060 & $\varepsilon$ & 060 & $\varepsilon$ & 060 & $\varepsilon$ & 060 & $\varepsilon$ & 000 & & $06^{\circ} 0$ & $\varepsilon$ & 000 & & 000 & & $0 \varepsilon^{0} 0$ & 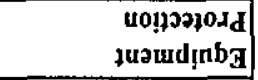 \\
\hline $0 z^{\prime} 0$ & $\mathfrak{l}$ & $0+0$ & $\tau$ & $09^{\circ} 0$ & $\varepsilon$ & 090 & $\varepsilon$ & $090^{\circ}$ & $\varepsilon$ & $09^{\circ} 0$ & $\mathfrak{\varepsilon}$ & $00^{\circ} 0$ & & $0 z^{\prime} 0$ & 1 & $00^{\circ} 0$ & & $00^{\circ} 0$ & & $0 z 0$ & S!!!!qвxวdo \\
\hline sio & $\varepsilon$ & olo & $\tau$ & oro & $z$ & oro & $\tau$ & oro & $\tau$ & oro & $z$ & $00^{\circ} 0$ & & $\$ 0^{\circ} 0$ & I & $00^{\circ} 0$ & & 00.0 & & $s 0^{\circ} 0$ & 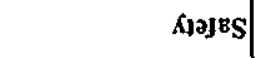 \\
\hline 0E0 & I & $09^{\circ} 0$ & $z$ & 060 & $\varepsilon$ & $06^{\circ} 0$ & $\varepsilon$ & 090 & $z$ & $06^{\circ} 0$ & $\varepsilon$ & 000 & & $06^{\circ} 0$ & $\varepsilon$ & 000 & & 000 & & $00^{0}$ & 2500 \\
\hline 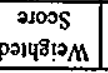 & atoos. & \begin{tabular}{|c|}
$\begin{array}{c}\text { 21025 } \\
\text { pasy???口M }\end{array}$ \\
\end{tabular} & 20oss; & 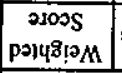 & oross: & \begin{tabular}{|c|}
21005 \\
p214
\end{tabular} & oooss. & 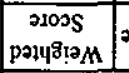 & pooss. & 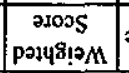 & 2005: & \begin{tabular}{|c|}
20025 \\
payq8? M
\end{tabular} & 2005s. & \begin{tabular}{|c|}
21005 \\
p2348?
\end{tabular} & $2005 \%$ & \begin{tabular}{|c|}
$2005 s$ \\
p2t48?
\end{tabular} & 2000s. & 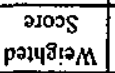 & 2005 . & & \\
\hline \multicolumn{2}{|c|}{ su!yıN oa } & \multicolumn{2}{|c|}{ 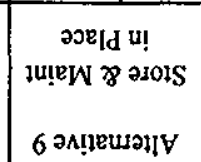 } & \multicolumn{2}{|c|}{ 8utping ןetaw } & \multicolumn{2}{|c|}{ 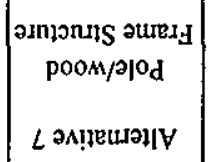 } & \multicolumn{2}{|c|}{ 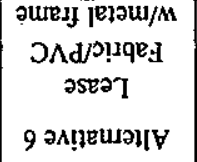 } & \multicolumn{2}{|c|}{ 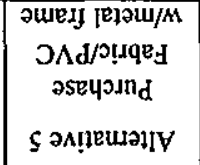 } & \multicolumn{2}{|c|}{ 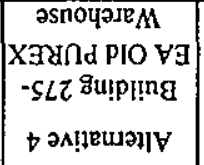 } & \multicolumn{2}{|c|}{ 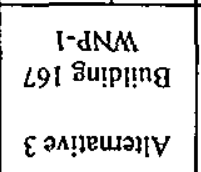 } & \multicolumn{2}{|c|}{ 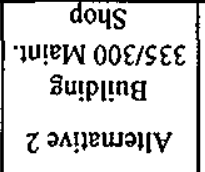 } & \multicolumn{2}{|c|}{ 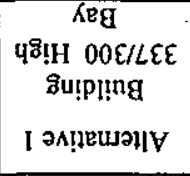 } & \multirow[t]{2}{*}{ 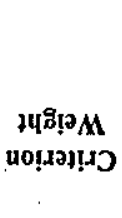 } & \multirow[t]{2}{*}{ 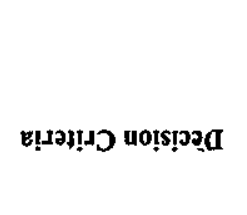 } \\
\hline & & & & & & & & & & & & & & & & & & & & & \\
\hline
\end{tabular}


HNF-4329, Rev. 0 .

Table 2. Decision Criteria Matrix for LLCERS New Storage Building

\begin{tabular}{|c|c|c|c|c|c|c|c|}
\hline \multirow{3}{*}{ Decision Criteria } & \multirow{3}{*}{$\begin{array}{c}\text { Criterion } \\
\text { Weight }\end{array}$} & \multicolumn{6}{|c|}{ Alternatives Evaluation } \\
\hline & & \multicolumn{2}{|c|}{$\begin{array}{c}\text { Alternative } 5 \\
\text { Purchase Fabric/PVC } \\
\text { w/metal frame }\end{array}$} & \multicolumn{2}{|c|}{$\begin{array}{c}\text { Alternative } 7 \\
\text { Pole/wood Frame } \\
\text { Structure }\end{array}$} & \multicolumn{2}{|c|}{$\begin{array}{l}\text { Alternative } 8 \\
\text { Metal Building }\end{array}$} \\
\hline & & *Score & $\begin{array}{l}\text { Weighted } \\
\text { Score } \\
\end{array}$ & *Score & $\begin{array}{l}\text { Weighted } \\
\text { Score }\end{array}$ & *Score & $\begin{array}{l}\text { Weighted } \\
\text { Score }\end{array}$ \\
\hline Cost & 0.30 & 2 & 0.60 & 3 & 0.90 & 1 & 0.30 \\
\hline Safety & 0.05 & 3 & 0.15 & 1 & 0.05 & 3 & 0.15 \\
\hline Operability & 0.20 & 3 & 0.60 & 1 & 0.20 & 3 & 0.60 \\
\hline $\begin{array}{l}\text { Equipment } \\
\text { Protection }\end{array}$ & 0.30 & & 0.00 & & 0.00 & & 0.00 \\
\hline Accountability & 0.05 & & 0.00 & & 0.00 & & 0.00 \\
\hline $\begin{array}{l}\text { Programmatic } \\
\text { Risk }\end{array}$ & 0.10 & & 0.00 & & 0.00 & & 0.00 \\
\hline Total & 1.00 & & 1.35 & & 1.15 & & 1.05 \\
\hline
\end{tabular}


HNF-4329, Rev. 0

Table 3. Decision Criteria Matrix for LLCERS Storage Facility Location

\begin{tabular}{|l|c|c|c|c|c|c|c|c|c|}
\hline \multirow{2}{*}{ Decision Criteria } & \multirow{2}{*}{$\begin{array}{c}\text { Criterion } \\
\text { Weight }\end{array}$} & \multicolumn{2}{|c|}{ Alternative 1 } & \multicolumn{2}{|c|}{ Alternative 2 } & \multicolumn{2}{c|}{ Alternative 3 } & \multicolumn{2}{c|}{ Alternative 4 } \\
\cline { 3 - 10 } & & $\begin{array}{c}\text { Cold Test Facility } \\
\text { Option 1 }\end{array}$ & $\begin{array}{c}\text { Cold Test Facliity } \\
\text { Option 2 }\end{array}$ & $\begin{array}{c}\text { Cold Test Facility } \\
\text { Option 3 }\end{array}$ & \multicolumn{2}{c|}{$\begin{array}{c}\text { Laydown Yard } \\
\text { North of 2704HV }\end{array}$} \\
\cline { 3 - 11 } & & *Score & $\begin{array}{c}\text { Weighted } \\
\text { Score }\end{array}$ & *Score & $\begin{array}{c}\text { Weighted } \\
\text { Score }\end{array}$ & $*$ Score & $\begin{array}{c}\text { Weighted } \\
\text { Score }\end{array}$ & *Score & $\begin{array}{c}\text { Weighted } \\
\text { Score }\end{array}$ \\
\hline Cost & $\mathbf{0 . 3 0}$ & 1 & 0.30 & 2 & 0.60 & 2 & 0.60 & 3 & 0.90 \\
\hline Safety & $\mathbf{0 . 0 5}$ & 3 & 0.15 & 3 & 0.15 & 3 & 0.15 & 1 & 0.05 \\
\hline Operability & $\mathbf{0 . 2 0}$ & 2 & 0.40 & 3 & 0.60 & 3 & 0.60 & 1 & 0.20 \\
\hline $\begin{array}{l}\text { Equipment } \\
\text { Protection }\end{array}$ & $\mathbf{0 . 3 0}$ & & 0.00 & & 0.00 & & 0.00 & & 0.00 \\
\hline Accountability & $\mathbf{0 . 0 5}$ & 1 & 0.05 & 1 & 0.05 & 1 & 0.05 & 3 & 0.15 \\
\hline Programmatic \\
Risk
\end{tabular}

$* 1=$ Poor, $2=$ Average, $3=$ Good 
TABLE 4. RPP LONG LENGTH CONTAMINATEDEQUIPMENT REMOVAL SYSTEM EQUIPMENT

\begin{tabular}{|c|c|c|c|c|c|c|c|c|c|c|c|c|}
\hline Item & Description & Belongs to & Comment & Lngth & Width & Ht & $\begin{array}{c}\text { Req'd } \\
F^{\prime 2}\end{array}$ & $\begin{array}{l}\text { Importance of } \\
\text { storage }\end{array}$ & $\begin{array}{l}\text { Material } \\
\text { Concerns } \\
\end{array}$ & $\begin{array}{c}\text { Type } \\
\text { (heat, weather) }\end{array}$ & $\begin{array}{c}\text { Replace } \\
\text { cost }\end{array}$ & Handle with \\
\hline 23 & $\begin{array}{l}\text { High Pressure Water } \\
\text { Washer on Trailer }\end{array}$ & $W-320$ & $\begin{array}{l}\text { HO-64-5257 } \\
\text { (store contaminated) }\end{array}$ & 224 in & 94 in & 95 in & 198 & High & $\begin{array}{l}\text { Hyd, elec, } \\
\text { automot }\end{array}$ & roof & high & pickup truck \\
\hline 25 & $\begin{array}{l}26 \text {-in Dia Poly Pipe } \\
\text { plus end caps }\end{array}$ & RPP & $\begin{array}{l}3 \text { ea } \\
\text { approx } 80 \mathrm{ft} \text { long }\end{array}$ & $73 \mathrm{ft}$ & 28 in DIA & & 900 & Low & & & & fork truck \\
\hline 26 & LLCE Long Lift Beam & RPP & $\begin{array}{l}\text { 30in l-beam, approx } 72 \text { ft long } \\
\text { (store contaminated) }\end{array}$ & $71 \mathrm{ft}$ & $24 \mathrm{I} n$ & 13 in & 296 & Moderate & Painted & $\operatorname{tarp}$ & moderate & fork truck \\
\hline 27 & $\begin{array}{l}\text { 106-C Pit A Work } \\
\text { Platform Large }\end{array}$ & $W-320$ & $\begin{array}{l}\text { WGS-XVV-375234 } \\
\text { S/N } 189296 \\
\text { (store contaminated) }\end{array}$ & $228 \mathrm{in}$ & $112 \mathrm{in}$ & 69 in & 177 & Low & & & & fork truck \\
\hline 28 & $\begin{array}{l}\text { 106-C Pit A Work } \\
\text { Platform Medium }\end{array}$ & W-320 & $\begin{array}{l}\text { WGS-XVV-375234 } \\
\text { S/N } 189289 \\
\text { (store contaminated) }\end{array}$ & 144in & $88.5 \mathrm{in}$ & 42 in & 89 & Low & & & & fork truck \\
\hline 29 & $\begin{array}{l}\text { 106-C Pit A Work } \\
\text { Platform Small }\end{array}$ & $\mathrm{W}-320$ & $\begin{array}{l}\text { WGS-XVV-378234 } \\
\text { S/N } 189049 \\
\text { (store contaminated) }\end{array}$ & 161 in & $168 \mathrm{in}$ & 24 in & 187 & Low & & & & fork truck \\
\hline 30 & $\begin{array}{l}34 \text { in Dia Pipe with } \\
\text { Flange }\end{array}$ & W-320 & & $130 \mathrm{in}$ & 43 in dia & & 72 & Moderate & Rust & roof & low & fork truck \\
\hline 31 & 72-in Dia Culvert & $W-320$ & & 99 in & 72 in dia & & 49 & Low & & & & fork truck \\
\hline 32 & Tower & W-320 & $\begin{array}{l}\text { approx } 50 \mathrm{ft} \text { tall } \\
\text { (store contaminated) }\end{array}$ & $42 \mathrm{ft}$ & 138 in & 100 in & 675 & Moderate & Painted & tarp & moderate & fork truck \\
\hline 33 & Rectangular Container & $W-320$ & $\begin{array}{l}\mathrm{H}-2-820736, \mathrm{~S} / \mathrm{N} 189254 \\
\text { (store contaminated) }\end{array}$ & 227 in & 89 in & 137 in & 140 & Low & & & . & fork truck \\
\hline 34 & $\begin{array}{l}\text { Rectangular Container } \\
42 \text {-in Flex receiver } \\
\text { Cartridge } 2 \text { each }\end{array}$ & W-320 & $\begin{array}{l}\text { H-2-79352/H-2-73359 } \\
\text { (numbers on only one) (store } \\
\text { contaminated) S/N's } 189203 \text { \& } \\
4\end{array}$ & $106 \mathrm{in}$ & 146 in & 114 in & 215 & Low & & & & fork truck \\
\hline 35 & $\begin{array}{l}\text { Rectangular Container } \\
\text { Sluicing Pit AY-02B }\end{array}$ & W-320 & $\begin{array}{l}\mathrm{H}-2-820735 \\
\text { (store contaminated) }\end{array}$ & 169 in & 162 in & 152 in & 190 & Low & & & & fork truck \\
\hline 36 & Short Tower & W-320 & (approx $10 \mathrm{ft}$ tall) & 233 in & 150 in & 136 in & 243 & Excess & & & & \\
\hline 37 & $\begin{array}{l}\text { Moveable, Elevated } \\
\text { Drum }\end{array}$ & W-320 & (approx $15 \mathrm{ft}$ tall) & 112 in & 99 in & 165 in & 76 & Excess & & & & \\
\hline 38 & $\begin{array}{l}\text { Rectangular Container } \\
\text { Heel Pit CR- } \\
\text { O6B W-320 }\end{array}$ & $W-320$ & $\begin{array}{l}\mathrm{H}-2-820737 \\
\mathrm{~S} / \mathrm{N} 189205 \\
\text { (store contaminated) }\end{array}$ & 150 in & 120in & 96 in & 125 & Low & & & & fork truck \\
\hline 39 & $\begin{array}{l}\text { Rectangular Container } \\
\text { Bag Assembly }\end{array}$ & W-320 & $\begin{array}{l}\text { H-2-79297 } \\
\text { (store contaminated) }\end{array}$ & 72 in & 49 in & 52 in & 24 & Low & & & & fork truck \\
\hline 40 & Rectangular Container & W-320 & $\begin{array}{l}\mathrm{S} / \mathrm{N} 189288 \\
\text { (store contaminated) }\end{array}$ & $111 \mathrm{in}$ & 82 in & 53 in & 63 & Low & & & & fork truck \\
\hline
\end{tabular}




\begin{tabular}{|c|c|c|c|c|c|c|c|c|c|c|c|c|}
\hline Item & Description & Belongs to & Comment & Lngth & Width & Ht & $\underset{F^{2}}{\text { Req'd }}$ & $\begin{array}{l}\text { Importance of } \\
\text { storage }\end{array}$ & $\begin{array}{l}\text { Material } \\
\text { Concerns }\end{array}$ & $\begin{array}{c}\text { Type } \\
\text { (heat, weather) }\end{array}$ & $\begin{array}{l}\text { Replace } \\
\text { cost }\end{array}$ & Handle with \\
\hline 41 & $\begin{array}{l}\text { Rectangular Container } \\
\text { 42-in Prototype Leak } \\
\text { Containment Bag }\end{array}$ & W-320 & $\begin{array}{l}\text { H-2-79362 } \\
\text { (store contaminated) }\end{array}$ & $111 \mathrm{in}$ & 82 in & 53 in & 63 & Low & & & & fork truck \\
\hline 42 & $\begin{array}{l}\text { Railings (3) and Plates } \\
\text { (2) }\end{array}$ & $W-320$ & (store contaminated) & $170 \mathrm{in}$ & 127 in & 24 in & 150 & Low & & & & fork truck \\
\hline 43 & LLCE Receiver Trailer & $\mathrm{RPP} / \mathrm{CPO}$ & $\begin{array}{l}\mathrm{HO}-64-4283 \\
\text { (store contaminated) }\end{array}$ & $83 \mathrm{ft}$ & 154 in & 172 in & 1800 & Moderate & $\begin{array}{l}\text { Hyd \& elec } \\
\text { equ }\end{array}$ & roof & enormous & semi tractor \\
\hline 44 & $\begin{array}{l}\text { LLCE Transportation } \\
\text { Trailer }\end{array}$ & $\mathrm{RPP} / \mathrm{CPO}$ & $\begin{array}{l}\mathrm{HO}-64-4280 \\
\text { (store contaminated) }\end{array}$ & $77 \mathrm{ft}$ & $154 \mathrm{in}$ & 163 in & 1700 & Moderate & $\begin{array}{l}\text { Hyd \& elec } \\
\text { equ }\end{array}$ & roof & enormous & semi tractor \\
\hline 45 & Conex Box $210526-0$ & RPP/CPO & $210526-0$ & 238 in & 97 in & 105 in & 160 & Negligible & & & & fork truck \\
\hline 46 & Trough & $\mathrm{RPP} / \mathrm{CPO}$ & (store contaminated) & $53 \mathrm{ft}$ & 97 in & 26 in & 550 & High & Paint \& rust & $\begin{array}{l}\text { turn over, refinish } \\
\text { and cover w/ tarp }\end{array}$ & moderate & fork truck \\
\hline 47 & Trough & $\mathrm{RPP} / \mathrm{CPO}$ & $\begin{array}{l}\text { containing two smaller troughs } \\
\text { (store contaminated) }\end{array}$ & $70 \mathrm{ft}$ & 87 in & 38 in & 666 & High & Paint \& rust & $\operatorname{tarp}(\sec 46)$ & moderate & fork truck \\
\hline 48 & Trough & RPP/CPO & Inverted (store contaminated) & 199 in & 88 in & 17 in & 190 & High & Paint \& rust & $\operatorname{tarp}(\sec 46)$ & moderate & fork truck \\
\hline 49 & Ring & $\mathrm{RPP} / \mathrm{CPO}$ & (store contaminated) & 61 in dia & & 8 in & 49 & High & Rust & Conex & low & fork truck \\
\hline 50 & Trough & RPP/CPO & (store contaminated) & 53 in & 98 in & $42 \mathrm{in}$ & 550 & High & Paint \& rust & $\operatorname{tarp}(\sec 46)$ & moderate & fork truck. \\
\hline 51 & Trough & $\mathrm{RPP} / \mathrm{CPO}$ & (store contaminated) & $70 \mathrm{ft}$ & $19.5 \mathrm{in}$ & 22 in & 284 & High & Paint \& rust & $\operatorname{tarp}(\sec 46)$ & moderate & fork truck \\
\hline 52 & Trough. & $\mathrm{RPP} / \mathrm{CPO}$ & (store contaminated) & $53 \mathrm{ft}$ & 98 in & 28 in & 550 & High & Paint \& rust & $\operatorname{tarp}(\sec 46)$ & moderate & fork truck \\
\hline 53 & Box & RPP/CPO & end caps & 60 in & 59 in & $29 \mathrm{in}$ & 25 & Negligible & & Conex & & fork truck \\
\hline 54 & Jack Platform & $\mathrm{RPP} / \mathrm{CPO}$ & (store contaminated) & 125 in & 96 in & 86 in & 120 & High & Paint & roof & moderate & fork truck \\
\hline 55 & Trough & RPP/CPO & (store contaminated) & 199 in & 89 in & 32 in & 171 & High & Paint \& rust & $\operatorname{tarp}(\sec 46)$ & moderate & fork truck \\
\hline 56 & Trough & $\mathrm{RPP} / \mathrm{CPO}$ & Inverted (store contaminated) & 199 in & 88 in & 26 in & 171 & High & Paint \& rust & $\operatorname{tarp}(\sec 46)$ & moderate & \\
\hline 57 & Box & RPP/CPO & & 30 in & 44 in & 24 in & 9 & High & Wood & Conex & low & fork truck \\
\hline 58 & Cradles (wooden) & $\mathrm{RPP} / \mathrm{CPO}$ & $8 \mathrm{ea}$ & $8 \mathrm{ft}$ & 10 in & $4 \mathrm{ft}$ & 53 & Low & & Conex & & \\
\hline 59 & Tall Box (wooden) & RPP/CPO & & 38 in & 38 in & 69 in & 10 & Moderate & Wood & Conex & small & fork truck \\
\hline 60 & Boxes (wooden) & $\mathrm{RPP} / \mathrm{CPO}$ & $4 \mathrm{ea}$ & 49 in & 22 in & 24 in & 29 & Moderate & Wood & Conex & small & \\
\hline \multicolumn{13}{|c|}{ COLD TEST FACILITY } \\
\hline 119.1 & Conex $3 / 4$ full & SY-101 & I ea & $40 \mathrm{ft}$ & 95 in & 102 in & 633 & Negligible & & & & crane \\
\hline 119.2 & Conex, $1 / 2$ full & $\mathrm{W}-320$ & $1 \mathrm{ea}$ & $40 \mathrm{ft}$ & $95 \mathrm{ft}$ & 102 in & 633 & Negligible & & & & crane \\
\hline \multicolumn{13}{|c|}{ IN FENCED YARD NE OF 241-C } \\
\hline 142 & $\begin{array}{l}\text { Big Yellow Burial } \\
\text { Containers H-2-83725 }\end{array}$ & W-320 & $3 \mathrm{ea}$ & $64 \mathrm{ft}$ & 43 in & 46 in & 990 & Moderate & Paint & & high & fork truck \\
\hline 143 & $\begin{array}{l}\text { Cover for burial } \\
\text { container } \mathrm{H}-2-83722\end{array}$ & W-320 & 1 ea & 66 in & 49 in & 8.5 in & 56 & Moderate & Paint & & low & fork truck \\
\hline 144 & $\begin{array}{l}\text { Pallets of Brackets } \\
\mathrm{H}-2-82073\end{array}$ & W-320 & $\begin{array}{l}3 \text { ea } \\
\text { (store contaminated) }\end{array}$ & 40 in & 32 in & & 27 & Moderate & Paint & Conex & low & fork truck \\
\hline 145 & Yoke H-2-820741 & W-320 & $\begin{array}{l}\text { l ea } \\
\text { (store contaminated) }\end{array}$ & 48 in & 34 in & 11 in & 11 & High & Paint \& rust & Conex & high & fork truck \\
\hline
\end{tabular}




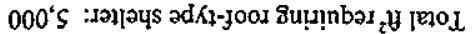

\begin{tabular}{|c|c|c|c|c|c|c|c|c|c|c|c|c|}
\hline & & & & & $000^{\circ} \mathrm{SI}$ & & & & & & TYIOL & \\
\hline Xָon Xiog & ว1Еsəpou & xəư & & әाеәроW & 08 & & ข $\varepsilon$ & ४ 9 & eə $\tau$ & $\begin{array}{l}\text { OdJ } \\
\text { /ddd }\end{array}$ & KSS $\forall$ पSEM & 0 \\
\hline yon yIof & 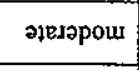 & J00I & & әемәроW & $0 \pitchfork z$ & & \& ZI & अ 9 & eəz & $\begin{array}{l}\text { OdO } \\
\text { /ddd }\end{array}$ & Kss joods & I \\
\hline 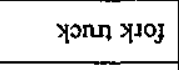 & ә1шгәроч & 5001 & & $\mathbf{4} ! \mathrm{H}$ & 982 & & $\forall S I$ & WSI & ह2 I & $\begin{array}{l}\text { OdD } \\
\text { /dd8 }\end{array}$ & wojeld & a \\
\hline Xפח & $489 ! 4$ & J00I & & ч8ะ! & $8 Z I$ & & & घ!̣ ४ 9 & eə Z & $\begin{array}{l}\text { OdO } \\
\text { /ddd }\end{array}$ & 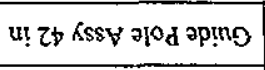 & $a$ \\
\hline צ' & 48:!4 & joox & & पุจ! & 821 & & & हाр \& 9 & eəz & $\begin{array}{l}\text { OdD } \\
\text { /ddd }\end{array}$ & $\begin{array}{r}\text { u!-Zz } \\
\text { KssV joods uolue!pey }\end{array}$ & 0 \\
\hline 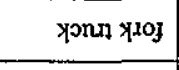 & 48ె!4 & xəuоว & & ә1егороW & 09 & & $\forall S$ & $\forall \varepsilon$ & səXog uo1ked $t$ & $\begin{array}{l}\text { OdD } \\
\text { /ddd }\end{array}$ & $\begin{array}{r}\text { sassaureH } \\
\text { o!nnexp } K_{H} \text { pure suy! } M\end{array}$ & $g$ \\
\hline X्रonn 저이 & $48 \div$ & joot & & 48्:H & 882 & & $\forall 0 I$ & $\forall 0 \mathrm{I}$ & eəz & $\begin{array}{l}\text { OdD } \\
\text { /ddy }\end{array}$ & 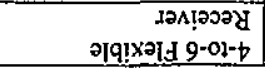 & v \\
\hline \multicolumn{13}{|c|}{ 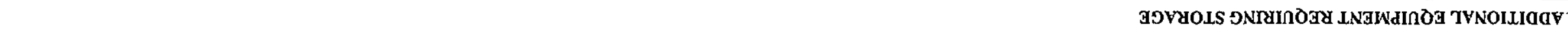 } \\
\hline 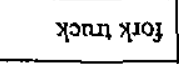 & әріәроu & dre? & zụpd & วчегароW & oz\& & u!zI & $\forall t \mathbf{i}$ & $\forall<I$ & ea I & $0 Z \varepsilon-M$ & $\begin{array}{r}\text { OELOZ8-ZH } \\
\text { usofjeId }\end{array}$ & $\angle b l$ \\
\hline 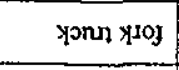 & әџезароu & xəuos & Iu!ed & әุеsәроW & $9 \varepsilon$ & 丩! દI & u & u! $Z \varsigma$ & 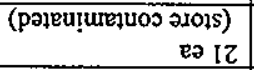 & $0 Z \varepsilon-M$ & $\begin{array}{r}\varsigma Z \angle \varepsilon 8-\tau-H \\
\text { slolled } \varepsilon \text { uo ‘səIpes } \\
\end{array}$ & $9 b l$ \\
\hline पџ!м ग्ршеН & $\begin{array}{c}\text { 150s } \\
\text { 20E|day }\end{array}$ & 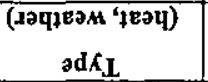 & 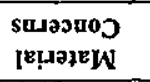 & 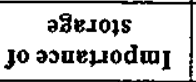 & p.boy & tH & q)р!M & ตนชิธา & zuวนแนo & 0) s8utuog & no!̣d!ussad & шаңI \\
\hline
\end{tabular}




\section{ENGINEERING STUDY}

\section{DETERMINATION OF STRUCTURE TYPE AND LOCATION FOR A STORAGE SHELTER FOR THE \\ LONG-LENGTH CONTAMINATED EQUIPMENT (LLCE)}

PREPARED FOR

\section{NUMATEC HANFORD CORPORATION}

MARCH 1999

PREPARED BY

Fluor Daniel Northwest, Inc

Richland, Washington 


\section{INTRODUCTION}

The Long-Length Contaminated Equipment (LLCE) was designed and built to aid in the remote removal and transport of highly radioactive, contaminated equipment from various locations in the tank farms to disposal. The LLCE represents a significant investment in state-of-the-art equipment and was specifically designed to perform all future equipment removals at the Hanford site. The LLCE has been stored in an open, lay-down area, exposed to the elements for the past one and one-half years.

\section{PURPOSE}

The purpose of this study was to investigate the possible options available to provide a shelter for the LLCE equipment to minimize damage from the weather. In addition, certain site improvements may be necessary, based on the existing site conditions, considering the size, weight, and maneuverability of the LLCE trailers. The options provided in the study include shelter types, locations and site improvements considered necessary to provide adequate access to the shelter.

If no action is taken to protect the equipment from prolonged exposure to the elements (wind, rain, snow and direct sunlight), deterioration of the more venerable components such as electrical wiring, hoses, gaskets and tires will occur. This condition will require a significant quantity of component replacement and potential re-testing of the LLCE systems.

\section{SUMMARY}

The study involved performing an investigation to: (1) define the type of structure needed and the associated site requirements, applicable to that type structure; (2) identify the types of shelters available and provide recommendations; (3) develop a rough cost estimate for each of the options selected. Specific options provided include three types of shelters, three proposed shelter locations and the selected site improvements to provide adequate access to the shelter site.

\section{DESCRIPTION}

The initial action of the study was to define the site design requirements, applicable to a storage type structure. The site requirements are based on the performance categories as defined in HNF-PRO-097. Based on this document, the subject building is considered performance category PC-0, as determined per Figure 1, page 4. Since no other references to specific requirements are provided, the minimum design requirements stated per page 2 of HNF-PRO-097, the Uniform Building Code (ICBO 1994) and 
American Society of Civil Engineers (ASCE) 7-95 for PC-0 will be implemented. Based on the categories established in the UBC for Use and Occupancy, the shelter has been categorized per Chapter 3, as a Group S, Division 2 (S-2) occupancy. The LLCE trailers are essentially constructed of noncombustible materials, excluding small quantities of flammable material (i.e hydraulic and lubricating oils) contained in reservoirs inside the equipment, which are normally inaccessible.

Based on the requirements, a listing was developed which sampled the various types of structures available. The search revealed three basic types of shelters which would satisfy the design criteria and the space envelop. The three types shelters consist of: (1) a pole and wood frame structure with metal roof and siding; (2) a steel-arched frame supporting a fabric membrane and (3) a rigid frame, steel structure with corrugated metal walls and roof.

Rough cost estimates were obtained from vendors for each shelter type, assuming the structure would be purchased and built as any commercial building would be outside the Hanford site by the vendor. The cost figures reflect variations in the actual coverage provided by the shelter to better assess needs verses cost.

Cost estimates for the necessary site improvements were developed, based on three options, representing three shelter locations and the proposed routings to each.

Descriptions of conditions at the locations are identified in Figures 3 and 4 (drawings ESLLCE-01, Sheets 1 and 2) which require site improvements are summarized as follows:

Locations 1 and 2: Area 1 at the intersection of the secondary road and Route 4S will require approximately 300 cubic yards of compacted fill and 50 linear feet of culvert to widened the approach and accommodate the $48^{\prime}-3$ " turning radius of the LLCE trailers. In addition, Area 2 will require fill to elevate the general approach area from Route $4 \mathrm{~S}$ up to the first slope (upgrade) west of Route $4 \mathrm{~S}$. The road way from Route $4 \mathrm{~S}$ to the shelter site will require approximately 8 "crushed stone base to provide adequate support for the anticipated $49 \mathrm{lbs} / \mathrm{in}^{2}$ or $7 \mathrm{kips} / \mathrm{ft}^{2}$ maximum wheel loads from LLCE trailers.

Locations 3 and 4: The existing turning radius at these areas are acceptable for the LLCE, however grading will be required to provide a level road surface and uniform curvature. These areas will require the 8 "of crushed stone as noted at Locations 1 and 2.

Locations 5: The existing cross-site transfer line crosses the secondary road at two locations, based on the routing selected. These crossings will require special evaluation and consideration to assure the integrity of the transfer system is maintained. Further engineering evaluation will be required at these locations.

Locations 6,7 and 8: Areas 6,7 and 8 depict the proposed locations for removal of the existing steam line to allow access to the proposed LLCE storage shelter sites (Options 2 and 3 ). 


\section{CONCLUSIONS AND RECOMMENDATIONS}

The results of the study are summarized in Figures 1 through 5 . The study has revealed three types of structures, which satisfies the design criteria requirements for the LLCE storage shelter. Figure 1 provides a listing of shelter types, the shelter manufacturer and a rough estimate for each. The estimated costs provided, include options to purchase either a partially enclosed or totally enclosed shelter. Leasing options were also provided where available

Figure 2 is a cost summary and comparison of the proposed site improvements as determined necessary to provide adequate site access.

Based on the results of the study, the most versatile shelter type is the structural frame and membrane system. This system can be located, relocated or removed as necessary with little effort. The pole type and metal buildings are essentially permanent shelters requiring more substantial foundations. Considering basic cost, the pole structure represents the least costly of all types investigated, however foundation costs are not included in the figures shown. The foundation costs may however, be minimized through the design approach and result in this option being the most attractive.

The recommended shelter types are either, the pole frame $\mathrm{w} /$ metal roof and siding or the steel frame/membrane type structure.

The recommended building location is identified as Option 3, with access to and from the site identified as route 2 . This option is the least costly and represents the most functionally useful of the three options presented.

\section{REFERENCES}

ICBO - International Conference of Building Officials, Uniform Building Code (1994)

DOE-STD-1020-94, Natural Phenomena Hazards Design and Evaluation Criteria for Department of Energy Facilities, Change 1 (1996)

DOE-STD-1067-94, Guideline to Good Practices for Maintenance Facilities, Equipment and Tools at DOE Nuclear Facilities

\section{PROJECT HANFORD POLICY AND PROCEDURE SYSTEM}

HNF-PRO-097, Rev.0, Engineering Design and Evaluation 
A rough estimate for each type of shelter is provided in the following table. The comparisons provided, reflect the costs for a roofed shelter and the cost for an enclosed or partially enclosed shelter, considering the type selected. The cost estimates are based on a structure $60 \mathrm{ft} \times 120 \mathrm{ft}$ with a $20 \mathrm{ft}$ clear ceiling height for the full $60 \mathrm{ft}$ width.

\begin{tabular}{|l|l|c|c|c|}
\hline Type of Shelter & \multicolumn{1}{|c|}{ Shelter Vendor } & $\begin{array}{c}\text { Cost w/ } \\
\text { Roof only }\end{array}$ & $\begin{array}{c}\text { Cost } \\
\text { Enclosed }\end{array}$ & $\begin{array}{c}\text { Rental term } \\
\text { Cost/month }\end{array}$ \\
\hline $\begin{array}{l}\text { Pole Construction/ } \\
\text { (Metal Roof/ } \\
\text { Walls) }\end{array}$ & $\begin{array}{l}\text { "Quality Steel Buildings", Inc. } \\
\text { Spokane, WA. }\end{array}$ & $\$ 28 \mathrm{k}$ & $\$ 55 \mathrm{k}$ & $\mathrm{NA}$ \\
\hline Metal Building & $\begin{array}{l}\text { "Butler Bldg. Systems", } \\
\text { Shamrock Construction }\end{array}$ & $\$ 79 \mathrm{k}$ & $\begin{array}{c}\$ 115 \mathrm{k} \\
(\text { Enclosed } \\
\text { one side, } \\
\$ 86.4 \mathrm{k})\end{array}$ & $\mathrm{NA}$ \\
\hline $\begin{array}{l}\text { Steel Frame w/ } \\
\text { Fabric Membrane }\end{array}$ & $\begin{array}{l}\text { "Rubb Building } \\
\text { Systems", Satellite } \\
\text { Shelters International, } \\
\text { Inc. } \\
\text { Port Townsend, WA. }\end{array}$ & $\$ 89 \mathrm{k}$ & $\$ 120 \mathrm{k}$ & $\begin{array}{r}2 \mathrm{yr} / \$ 4.0 \mathrm{k} \\
3 \mathrm{yr} / \$ 3.0 \mathrm{k} \\
5 \mathrm{yr} / \$ 2.5 \mathrm{k}\end{array}$ \\
\hline $\begin{array}{l}\text { Aluminum Arched } \\
\text { Frame w/ PVC } \\
\text { membrane }\end{array}$ & $\begin{array}{l}\text { Sprung Instant } \\
\text { Structures, Inc. Salt Lake } \\
\text { City, Utah }\end{array}$ & $\$ 90 \mathrm{k}$ & $\$ 95 \mathrm{k}$ & $\begin{array}{r}2 \mathrm{yr} / \$ 2.6 \mathrm{k} \\
(\mathrm{w} / \mathrm{roof} \text { only) } \\
2 \mathrm{yr} / \$ 2.7 \mathrm{k} \\
\text { (enclosed) }\end{array}$ \\
\hline
\end{tabular}

Figure 1, Summary Cost Comparison for each type Shelter 
The following table provides a summary of cost estimates for site improvements to provide access to each shelter, based on the routing used.

\begin{tabular}{|c|c|c|c|}
\hline $\begin{array}{c}\text { OPTION NO. } \\
\text { (Bldg location) }\end{array}$ & $\begin{array}{c}\text { COST (ROUTE 1) } \\
\text { (See Note 3) }\end{array}$ & $\begin{array}{c}\text { COST (ROUTE 2) } \\
\text { (See Note 4) }\end{array}$ & $\begin{array}{c}\text { COST (ROUTE 3) } \\
\text { (See Note 5) }\end{array}$ \\
\hline 1 & $\$ 160 \mathrm{k}$ & $\$ 120 \mathrm{k}$ & $\$ 180 \mathrm{k}$ \\
\hline 2 & $\$ 156 \mathrm{k}$ & $\$ 102 \mathrm{k}$ & $\$ 162 \mathrm{k}$ \\
\hline 3 & $\$ 163 \mathrm{k}$ & $\$ 102 \mathrm{k}$ & $\$ 165 \mathrm{k}$ \\
\hline
\end{tabular}

Figure 2, Summary Cost Comparison for each Routing

NOTES:

1) Refer to drawing Figures 3 and 4 (ES-LLCE-01, Sheets 1 and 2) for the proposed access routes and locations of recommended site improvements.

2) Refer to drawing Figure 5 (ES-LLCE-01, Sheet 3) for the proposed shelter locations.

3) Route 1 utilizes the secondary road starting at Route 4 and running parallel to Route 3 to the Cold Test Facility for access into and from the site.

4) Route 2 utilizes access from Route 3, adjacent to the Cold Test Facility for access into and from the site.

5) Route 3 utilizes the secondary road for access into the site and Route 3 adjacent to the Cold Test Facility for exit from the site. 
HNF-4329, Rev. 0

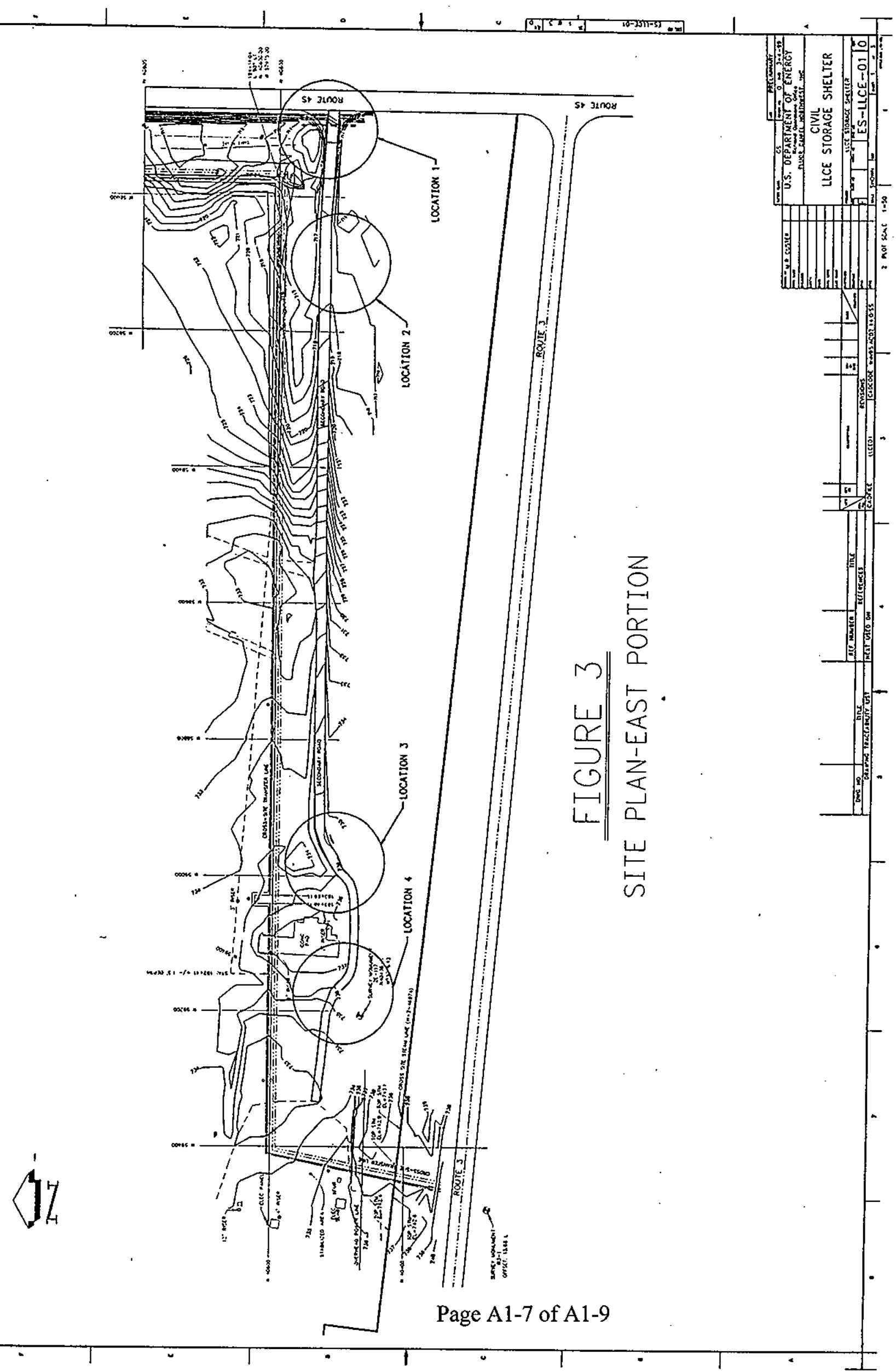


HNF-4329, Rev. 0

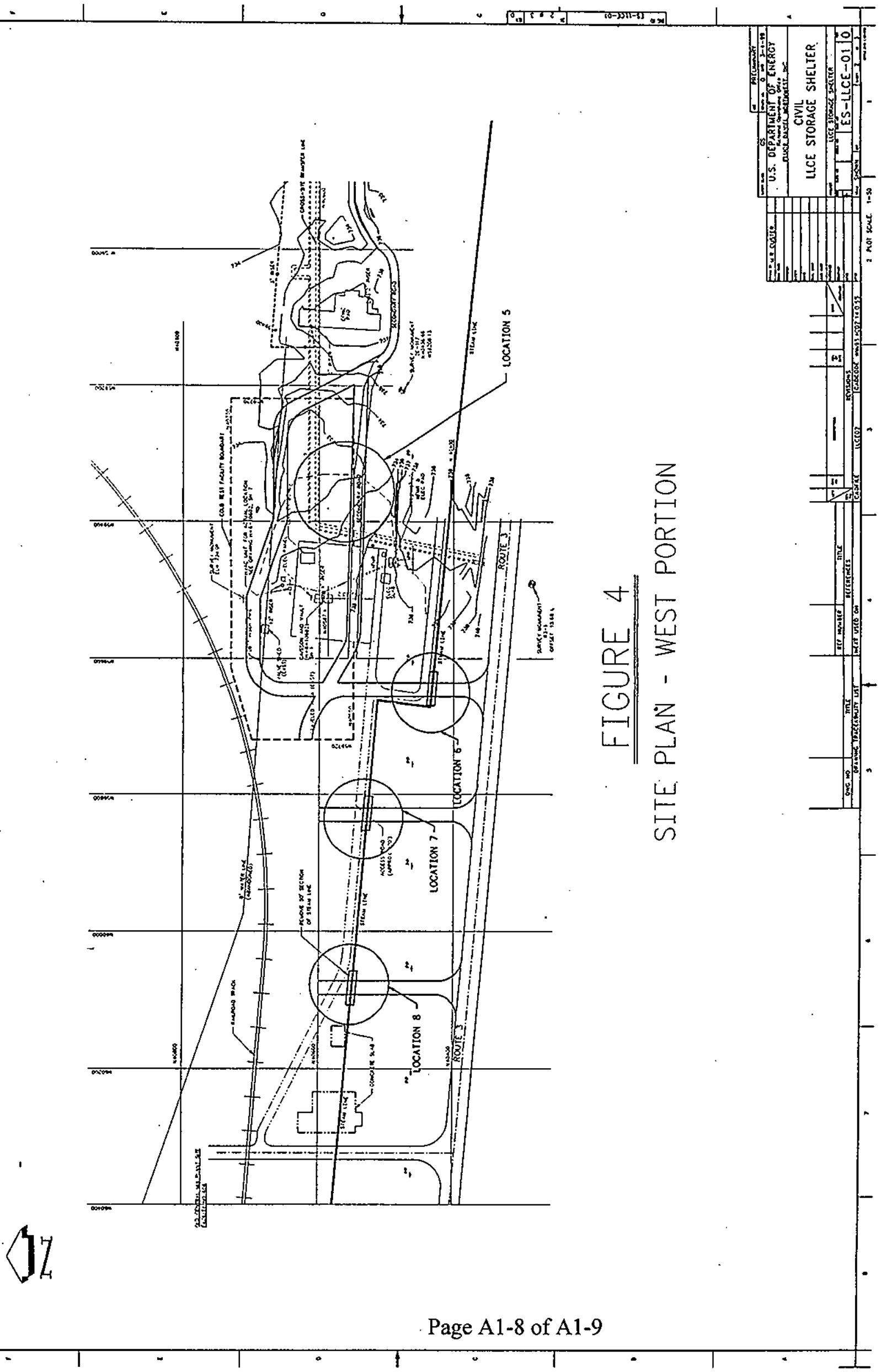


HNF-4329, Rev. 0

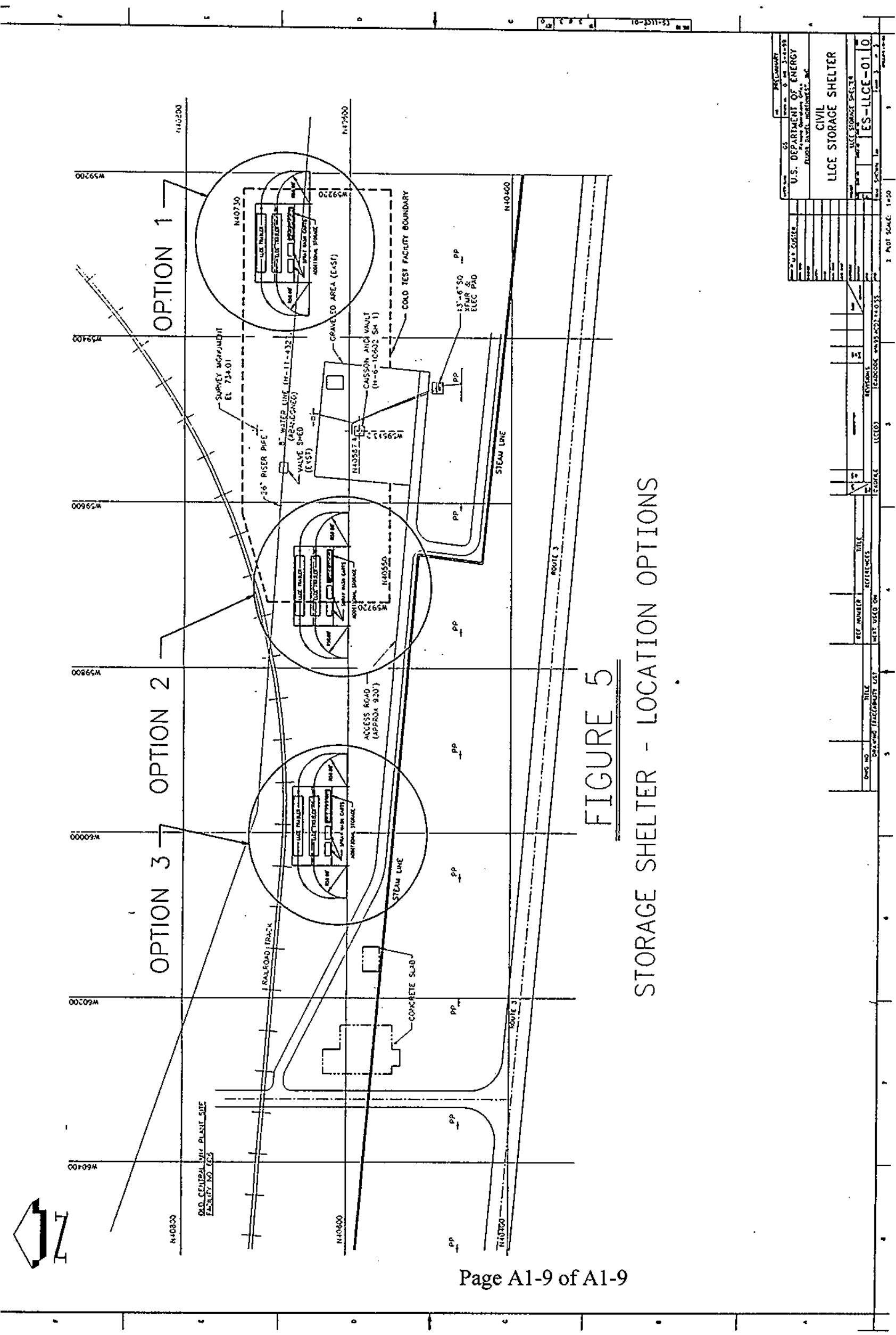


FINAL REPORT

\section{DETERMINATION OF STRUCTURE TYPE AND LOCATION FOR A STORAGE SHELTER FOR THE \\ LONG-LENGTH CONTAMINATED EQUIPMENT (LLCE)}

PREPARED FOR

\section{NUMATEC HANFORD CORPORATION}

MAX 1999

PREPARED BY

Fluor Daniel Northwest, Inc Richland, Washington 
HNF-4329, Rev. 0

\section{INTRODUCTION}

The Long-Length Contaminated Equipment (LLCE) was designed and built to remove and transport highly radioactive, contaminated equipment from various locations in the tank farms to disposal. The LLCE representing a significant investment in equipment has been stored in an open, lay-down area, exposed to the elements for the past one and onehalf years. A study completed in March 1999, provides a portion of the background information for the final selection of a LLCE shelter.

\section{PURPOSE}

The purpose of this report is to summarize the final results of the evaluation performed by the LLCE Decision Board and to describe the final shelter type, location and required site improvements.

\section{SUMMARY}

The results of the evaluation conclude that the Steel Frame w/ Fabric Membrane shall be the final selection of shelter type. The structure will be located, as shown in Figure 3 and the site improvements implemented, as described in Section IV and shown in Figure 3.

\section{DESCRIPTION}

The final selection of structure type, location and site improvements was the results of an evaluation of alternatives, based on a pre-defined selection criteria which reflected the critical attributes necessary to best satisfy all requirements.

The Steel Frame w/ Fabric Membrane structure, located as shown in Figure 3 was the final selection of structure type which best satisfied the selection criteria.

The final location of the shelter is approximately 400 feet west of the riser pit caisson at the Cold Test Facility (CTS), as shown in Figure 3.

A summary of required site improvements at the final shelter location are shown in Figure 3 and as described as follows:

Locations 1 and 2: The entrance and exit at Route 3 will require the installation of approximately 50 linear feet of culvert at each location to widened the approach and accommodate the $48^{\prime}-3$ " turning radius of the LLCE trailers. In addition, each location will require the installation of compacted fill and approximately 8"crushed stone base to provide adequate bearing support for the anticipated wheel loads from LLCE trailers.

Locations 3 and 4: The entrance and exit roadways to and from the shelter site shall require grading, compacted fill and 8 " of crushed stone base installed up and through the length of the shelter structure.

Locations 5 and 6: Areas 5 and 6 depict the locations for removal of approximately 50 linear feet of the existing steam line to allow access to the LLCE storage shelter site. 


\section{CONCLUSIONS}

The final configuration of the shelter site and access is summarized in Figure 3.

Figure 1 and 2 provides the cost summaries for the selected shelter type and required site improvements.

The recommended shelter type is the steel frame/membrane type structure.

A rough estimate for the shelter is provided in the following table. The costs provided are for either a roofed only shelter or totally enclosed. The estimates are based on a structure $60 \mathrm{ft} \times 120 \mathrm{ft}$ with a $20 \mathrm{ft}$ clear ceiling height for the full $60 \mathrm{ft}$ width.

\begin{tabular}{|l|l|c|c|c|}
\hline \multicolumn{1}{|c|}{ Type of Shelter } & \multicolumn{1}{|c|}{ Shelter Vendor } & $\begin{array}{c}\text { Cost } \mathrm{w} / \\
\text { Roof only }\end{array}$ & $\begin{array}{c}\text { Cost } \\
\text { Enclosed }\end{array}$ & $\begin{array}{l}\text { Rental term } \\
\text { Cost/month }\end{array}$ \\
\hline $\begin{array}{l}\text { Steel Frame w/ } \\
\text { Fabric Membrane }\end{array}$ & $\begin{array}{l}\text { "Rubb Building } \\
\text { Systems", Satellite } \\
\text { Shelters International, } \\
\text { Inc. } \\
\text { Port Townsend, WA. }\end{array}$ & $\$ 89 \mathrm{k}$ & $\$ 120 \mathrm{k}$ & $\begin{array}{r}2 \mathrm{yr} / \$ 4.0 \mathrm{k} \\
3 \mathrm{yr} / \$ 3.0 \mathrm{k} \\
5 \mathrm{yr} / \$ 2.5 \mathrm{k}\end{array}$ \\
\hline $\begin{array}{l}\text { Aluminum Arched } \\
\text { Frame w/ PVC } \\
\text { membrane }\end{array}$ & $\begin{array}{l}\text { Sprung Instant } \\
\text { Structures, Inc. Salt Lake } \\
\text { City, Utah }\end{array}$ & $\$ 90 \mathrm{k}$ & $\$ 95 \mathrm{k}$ & $\begin{array}{c}2 \mathrm{yr} / \$ 2.6 \mathrm{k} \\
(\mathrm{w} / \mathrm{roof} \text { only) } \\
2 \mathrm{yr} / \$ 2.7 \mathrm{k} \\
\text { (enclosed) }\end{array}$ \\
\hline
\end{tabular}

Figure 1, Cost Summary for the Shelter

The following table provides a cost summary for site improvements to provide access to the shelter, based on the final routing and shelter location selected.

\begin{tabular}{|c|c|c|c|}
\hline OPTION NO. & COST (ROUTE 1) & COST (ROUTE 2) & COST (ROUTE 3) \\
\hline 3 & N/A & $\$ 102 \mathrm{k}$ & N/A \\
\hline
\end{tabular}

NOTES:

Figure 2, Cost Summary for Site Improvements

1) Route 2 utilizes access from Route 3 , adjacent to the Cold Test Facility for access into and from the site. 
HNF-4329, Rev. 0

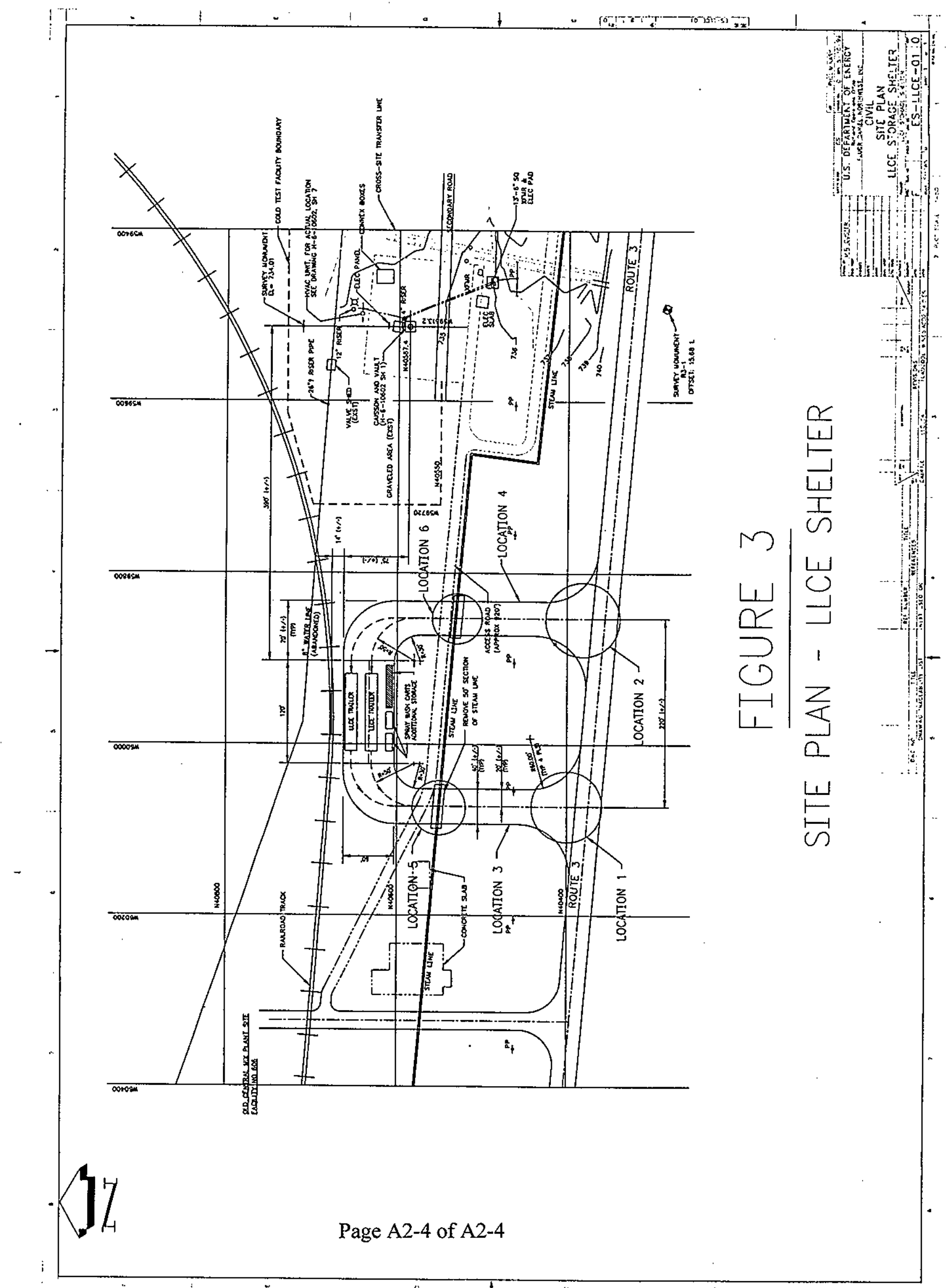




\section{DECISION PLAN}

FOR THE

\section{STORAGE AND MAINTENANCE ACTIVITIES OF CHARACTERIZATION LONG LENGTH CONTAMINATED EQUIPMENT REMOVAL SYSTEM}

\subsection{DECISION STATEMENT}

Major pieces of Characterization Sampling Equipment are currently stored outdoors. This includes the Long Length Contaminated Equipment Removal System (LLCERS). A decision is required to determine the preferred alternative for facilities to store and maintain this equipment.

The following alternatives shall be considered as a minimum:

- Use existing facilities

- $\quad$ Procure temporary facilities

- Construct new facilities

- Maintain and store in place

- No action

\subsection{DECISION CLASS}

The storage and maintenance of the LLCERS is a Class IV decision. This decision has cost and program impacts to the Characterization Project.

\subsection{RESPONSIBILITIES}

\subsection{Decision Maker}

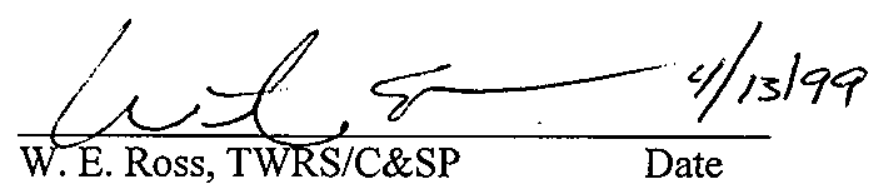

\subsection{Decision Action Officer}

\subsection{Decision Support Board}
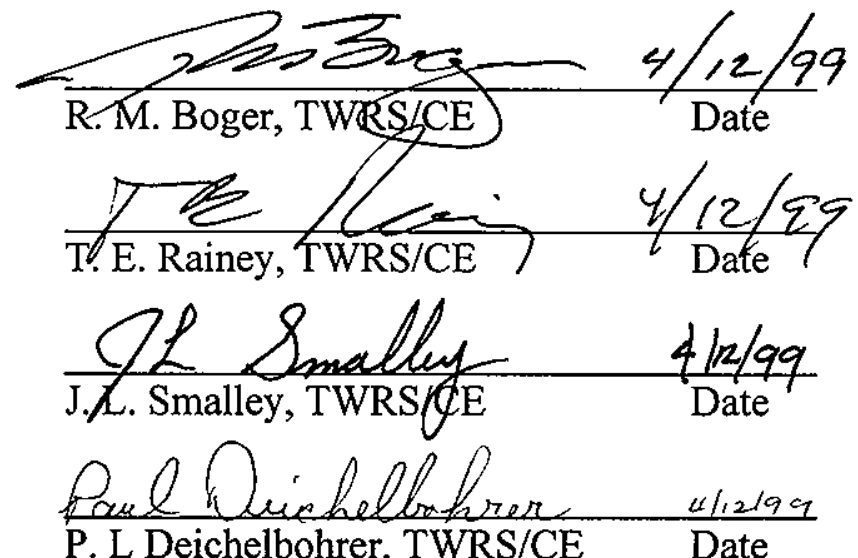


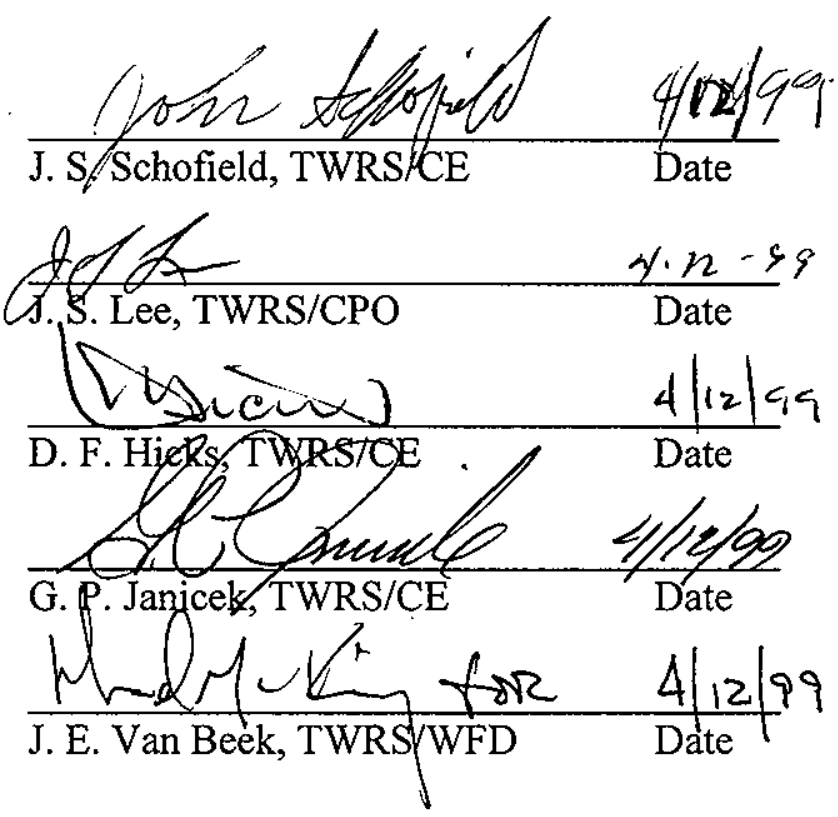

\subsection{DECISION STRATEGY}

The decision strategy will consist of initiating the development of the Alternative Generation and Analysis (AGA) Report with a Decision Analysis Summary for the Decision Maker (DM). The DM, with support of the Decision Support Board, will assign a weighting factor for each criterion establishing its level of importance. The Decision Support Group will review the AGA and/or the Decision Analysis Summary and evaluate alternatives against criteria. Presentations of the alternatives will be given to the DM. The DM will be responsible for the selection of a preferred alternative. The decision Action Officer will transfer the decision information to a formal Decision document.

\subsection{DECISION CRITERIA}

A decision criterion is a factor used to select a preferred alternative. The following relevant decision criteria were chosen for the conduct of the decision analysis process involved in the preparation of the AGA report and Decision Document.

- Cost: The cost of the alternative is the total cost with the assumption that the life cycle is complete within 10 years.

- Safety: Impact on the health and safety of Hanford Site Workers and the off-site population from radiological, toxicological, industrial, and environmental hazards associated with work site activities. Controlling radiation exposure to employees at levels that are as low as reasonably achievable (ALARA) shall be a primary goal. 
- Operability: "Ease of Use" operability measures to consider include preparation of equipment for first deployment, preventive maintenance (before deployment and after deployment), storage of contaminated equipment, and availability of equipment for training.

- Equipment Protection: The impact on the condition of the equipment while in storage, including the amount of degradation of parts and systems.

- Accountability: The physical security of all equipment.

- Programmatic risk: Alternatives are evaluated based on the ability to meet current and potential future requirements for equipment use.

\subsection{REQUIRED INFORMATION}

Required information includes the current operational location, physical size and condition of the LLCERS. The environmental storage requirements and maintenance required prior to use and during operation are required. An estimate of the current planned and projected level of activity for the future is needed.

\subsection{DECISION TIME FRAME}

Deliver a draft AGA report to all reviewers by April 8, 1999.

Hold Decision Analysis Board Meeting and deliver draft Decision Analysis Summary by April 20, 1999.

Issue Decision Document by April 29, 1999.

\subsection{ANTICIPATED INTERACTIONS WITH OTHER DECISIONS}

None

\subsection{EXTERNAL CONSTRAINTS}

An external constraint is the amount of funding available to implement the decision.

\subsection{CURRENT PLANNING BASIS}

The current activity provides limited funding for indoor storage of the LLCERS. 


\section{MEETING MINUTES}

HNF-4329, Rev. 0

SUBJECT: LLCERS Storage and Maintenance Activities Decision Support Board

\begin{tabular}{|c|c|c|c|c|}
\hline TO: & & BUILD & & \\
\hline W. E. Ross & & 2704 & & \\
\hline F. R. Rainey & & $\begin{array}{l}\text { CHAIR } \\
\text { R. I }\end{array}$ & jer & \\
\hline DEPARTMENT-OPERATIONN-CCMPONENT & AREA & SHIFT & DATE OF MEETING & NUMBER ATTENDING \\
\hline TWRS Characterization Project & $200 \mathrm{E}$ & & $4 / 12 / 99$ & 10 \\
\hline
\end{tabular}

The Decision Support Board for the decision to determine the preferred alternative for facilities to store and maintain the Long Length Contaminated Equipment Removal System (LLCERS) met to initiate the decision analysis process.

The Decision Action Officer (Mike Boger) and the Decision Support Board reviewed and approved the "Decision Plan for the Storage and Maintenance of Characterization Long Length Contaminated Equipment Removal System" (attacred).

$$
\text { ( } 3 \text {-ae Appandix } B \text { ) }
$$

A weighting factor for each criterion was determined relative to their degree of importance. Numerical values were assigned so that the total weight of all the criteria is equal to 1.00. The Criterion Weights are:
Cost
0.30
Safety
0.05
Operability
0.20
Equipment Protection 0.30
Accountability $\quad 0.05$
Programmatic Risk $\quad 0.10$

Comments received on the draft Alternatives Generation Analysis include:

Most of the equipment (including the trailers) should not be contaminated after use in tank farms. - Mike McKinney and Don Legare

The burial containers should be protected from sunlight - Don Legare

The equipment procured and owned by Project $W-211$ should be identified. - Mike McKinney

M. R. Custer should Review the AGA and be invited to the next meeting. - Mike Mckinney

The alternatives evaluation should be divided into two parts, type of facility and location (if new facility). - Tom Rainey

Remaining comments on the AGA are due to Paul Deichelbohrer by close of business 4/15/99.

The next meeting to evaluate the alternatives will be set up for Tuesday $4 / 20 / 99$. 


\section{LLCERS Storage and Maintenance Activities \\ Decision Board Meeting}

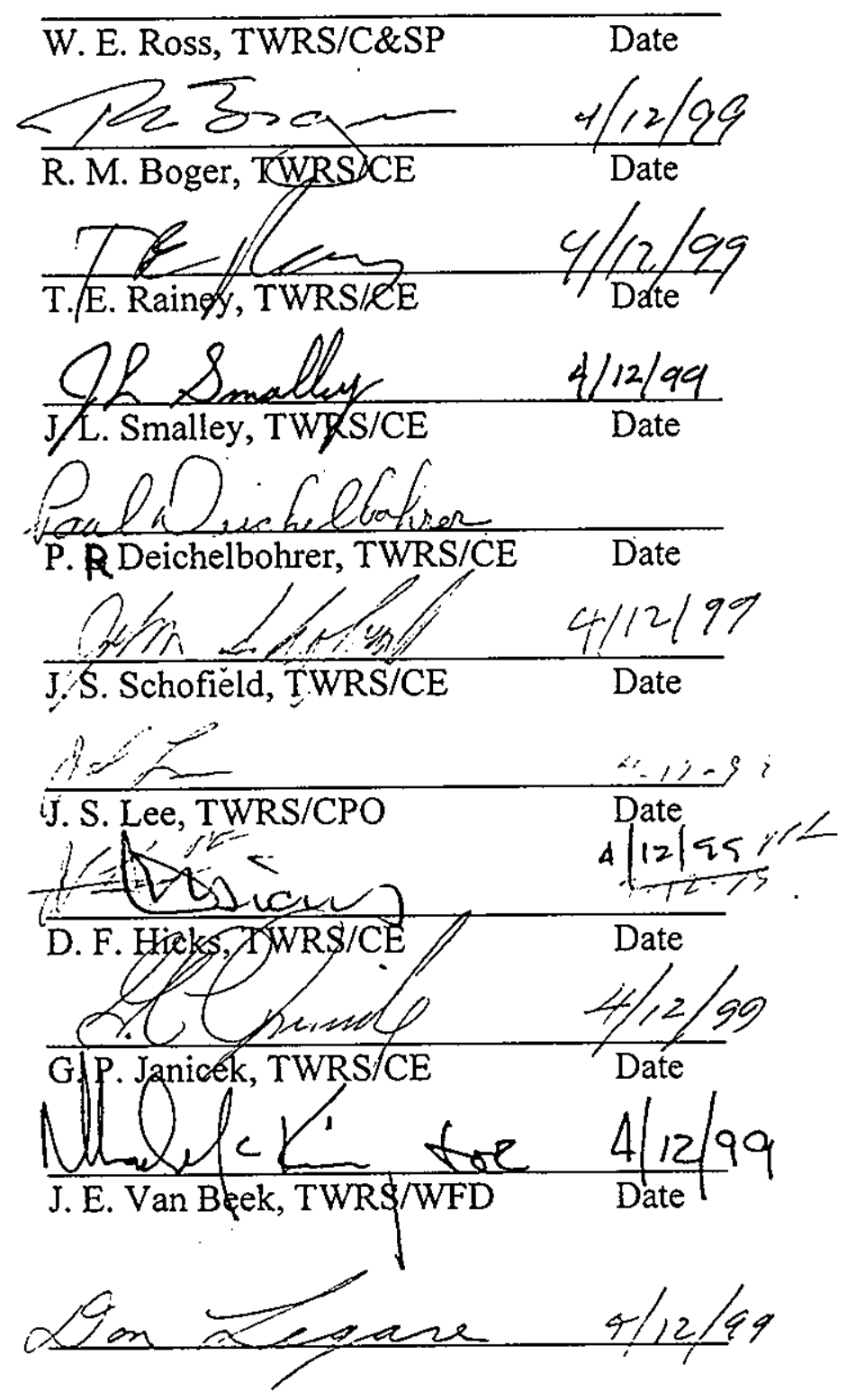


MEETING MINUTES

SUBJECT: Decision Board for the Storage of TWRS LLCERS

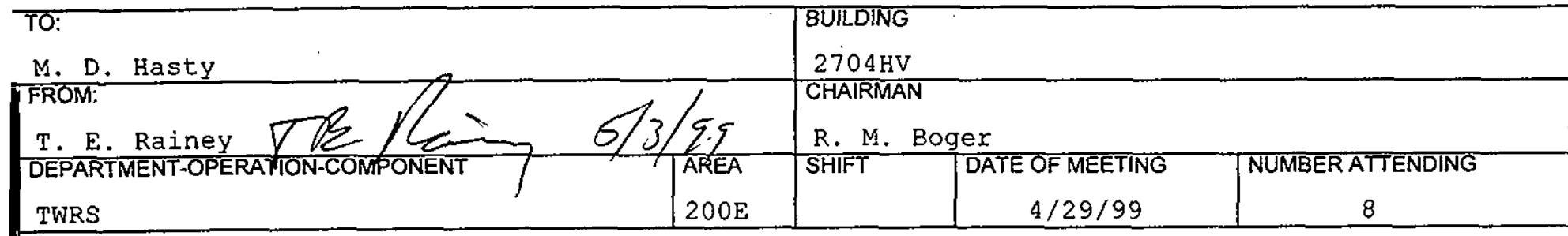

The decision board for the storage and maintenance activities for the Long Length

Contaminated Equipment Removal System (LLCERS) met to analyze the alternatives.

In earlier discussions between Project $\mathrm{W}-211$ (John Van Beek) and Characterization

Engineering (Mike Boger) it was determined that $\mathrm{W}-211$ would store the equipment purchased by $\mathrm{W}-211 / \mathrm{W}-151$ and the scope of this decision would only for equipment "owned" by

Characterization Project plus any additional equipment that would be purchased.

An alternative evaluation was completed for the ten alternatives using the approved decision criteria and criterion weights. After this analysis, three alternatives scored the same. These alternatives, Purchase a fabric/PVC structure, Purchase a pole building, and Purchase a metal building, were analyzed again separately.

A separate analysis was completed on where to locate the new structure.

The results of the analyses are that the decision board recommends that a fabric/PVC structure with a metal frame be purchased and located west of the cold test facility. The details of the analyses will be provided in the Alternatives Generation Analysis (AGA). 
HNF-4329, Rev. 0

DECISION BOARD MEETING FOR THE

STORAGE OF TWRS LLCERS

April 21, 1999

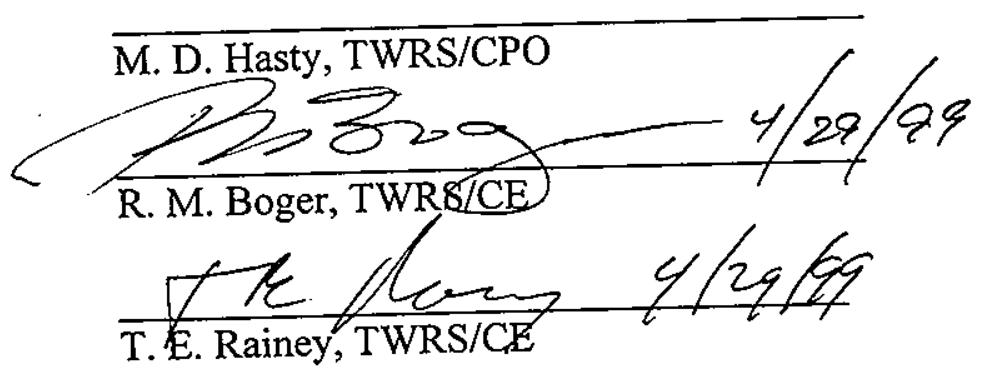

T. E. Rainey, TWRS/CE

J. L. Smalley, TWRS/CE

$\frac{\text { J. L. Smalley, TWRS/CE }}{\text { P. L Deichelbohrer, TWRS/CE }}$

J. S. Schofield, TWRS/CE

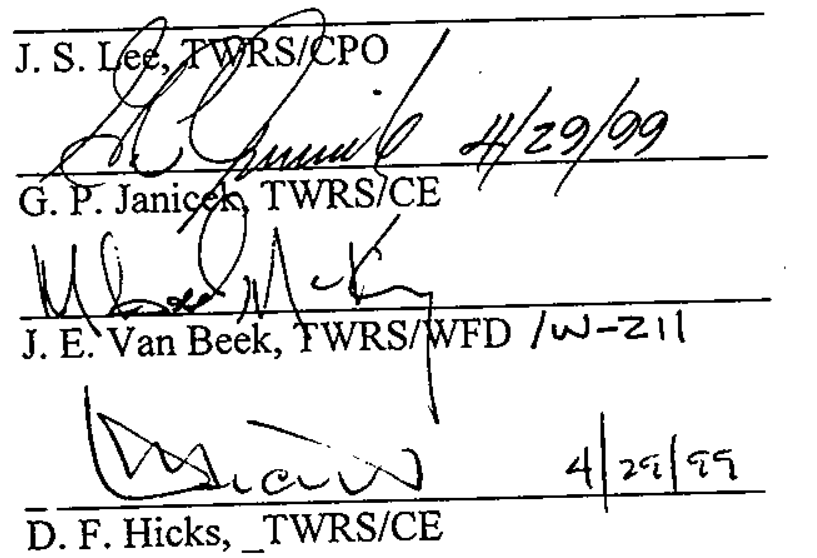

Michael R Cuats 4/29/99

M.RCuster

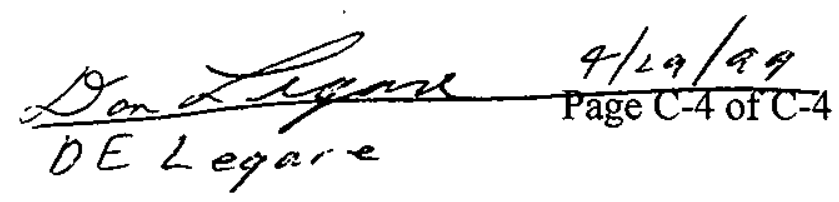


HNF-4329, Rev. 0

Appendix D

Compilation of Long Length Contaminated Equipment Removal System Equipment 
APPENDIXD

COMPILATION OF LONG LENGTH CONTAMINATEDEQUIPMENT REMOVAL SYSTEM EQUIPMENT

\begin{tabular}{|c|c|c|c|c|c|c|c|c|c|c|c|}
\hline Item & Description & Belongs to & Comment & Lngth & Width & Ht & Area $\mathrm{ft}^{2}$ & $\begin{array}{l}\text { Importance of } \\
\text { Storage }\end{array}$ & $\begin{array}{l}\text { Material } \\
\text { Concerns }\end{array}$ & $\begin{array}{c}\text { Replace } \\
\text { Cost }\end{array}$ & $\begin{array}{c}\text { Handle } \\
\text { With }\end{array}$ \\
\hline 1 & Burial Container & $\mathrm{W}-151 / 211$ & H-2-818192 sht 3 assy 3 & $65 \mathrm{ft}$ & 43 in & 46 in & 233 & moderate & painted & high & crane \\
\hline 2 & Poking tools & W-151/211 & 6 ea approx (store contaminated) & $21 \mathrm{ft}$ & $6 \mathrm{in}$ & 6 in & 10 & low & & & \\
\hline 5 & Strong Back & $\mathrm{W}-151 / 211$ & (store contaminated) & $64 \mathrm{ft}$ & 63 in & 32 in & 336 & moderate & painted & high & crane \\
\hline 7 & $\begin{array}{l}\text { Righting Semi- } \\
\text { trailer with } \\
\text { Strong Back }\end{array}$ & W-151/211 & HO-64-3531 (store contaminated) & $75 \mathrm{ft}$ & $8.5 \mathrm{ft}$ & $10 \mathrm{ft}$ & 638 & moderate & painted & high & $\begin{array}{l}\text { semi } \\
\text { tractor }\end{array}$ \\
\hline 9 & $\begin{array}{l}\text { Spare 4-to-6 Inch } \\
\text { Flexible Receiver }\end{array}$ & $\begin{array}{l}\text { W-151/211 } \\
\text { (Parts } \\
\text { missing) }\end{array}$ & $\begin{array}{l}\text { bar code: FA20877 } \\
\text { (store contaminated) }\end{array}$ & $9 \mathrm{ft}$ & $9 \mathrm{ft}$ & $12 \mathrm{ft}$ & 81 & high & hyd, elec & high & fork truck \\
\hline 12 & Winch Control & $\mathrm{W}-151 / 211$ & $\mathrm{H}-2.83777-020$ & $44 \mathrm{in}$ & 36 in & 65 in & 11 & moderate & paint & low & \\
\hline 14 & Boxes of Hoses & $W-151 / 211$ & $\begin{array}{l}2 \text { ea } \\
\text { (store contaminated) }\end{array}$ & 48 in & 24 in & $25 \mathrm{in}$ & 16 & high & $\begin{array}{l}\text { wood, } \\
\text { hose }\end{array}$ & low & fork truck \\
\hline 17 & $\begin{array}{l}\text { 12-wheeled } \\
\text { Semi-trailer }\end{array}$ & $W-151 / 211$ & $\begin{array}{l}\text { HO- } 64-5871 \text { with } 6 \text { outrigger pads } \\
\text { (store contaminated) }\end{array}$ & $70 \mathrm{ft}$ & $12 \mathrm{ft}$ & $14 \mathrm{ft}$ & 826 & moderate & painted & high & $\begin{array}{l}\text { semi } \\
\text { tractor }\end{array}$ \\
\hline 18 & $\begin{array}{l}\text { 54-inch Burial } \\
\text { Container }\end{array}$ & $W-151 / 211$ & $\begin{array}{l}2 \text { ea } \mathrm{H}-2-818142 \text { sht } 3 \text { Assy } 3 \\
\text { approx } 67 \mathrm{ft}\end{array}$ & $65 \mathrm{ft}$ & $6 \mathrm{ft}$ & $5 \mathrm{ft}$ & 344 & moderate & painted & moderate & crane \\
\hline 20 & $\begin{array}{l}\text { Spare Control } \\
\text { Trailer HO-64- } \\
3534, \mathrm{H}-2-79230\end{array}$ & W-151/211 & $\begin{array}{l}7 \text { spools wire/cable (instrument) } 2 \\
6 \text {-ft storage cabinets UPS Hose } \\
\text { Reel }\end{array}$ & $33 \mathrm{ft}$ & $8 \mathrm{ft}$ & $13 \mathrm{ft}$ & 260 & negligible & & $\cdot$ & $\begin{array}{l}\text { Pickup } \\
\text { truck }\end{array}$ \\
\hline 22 & $\begin{array}{l}\text { High Pressure } \\
\text { Washer on } \\
\text { Trailer }\end{array}$ & $W-151 / 211$ & $\begin{array}{l}\text { HO-64-3538 } \\
\text { WW-XVV-25701 } \\
\text { (store contaminated) }\end{array}$ & 224 in & 94 in & $95 \mathrm{in}$ & 146 & high & $\begin{array}{l}\text { hyd, elec, } \\
\text { automot }\end{array}$ & high & $\begin{array}{l}\text { Pickup } \\
\text { truck }\end{array}$ \\
\hline 23 & $\begin{array}{l}\text { High Pressure } \\
\text { Washer on } \\
\text { Trailer }\end{array}$ & W-320 & $\begin{array}{l}\text { HO-64-5257 } \\
\text { (store contaminated) }\end{array}$ & 224 in & $94 \mathrm{in}$ & $95 \mathrm{in}$ & 146 & high & $\begin{array}{l}\text { hyd, elec, } \\
\text { automot }\end{array}$ & high & $\begin{array}{l}\text { pickup } \\
\text { truck }\end{array}$ \\
\hline
\end{tabular}




\begin{tabular}{|c|c|c|c|c|c|c|c|c|c|c|c|}
\hline Item & Description & Belongs to & Comment & Lngth & Width & Ht & Area $\mathrm{ft}^{2}$ & $\begin{array}{c}\text { Importance of } \\
\text { Storage }\end{array}$ & $\begin{array}{l}\text { Material } \\
\text { Concerns }\end{array}$ & $\begin{array}{c}\text { Replace } \\
\text { Cost }\end{array}$ & $\begin{array}{c}\text { Handle } \\
\text { With }\end{array}$ \\
\hline 25 & $\begin{array}{l}26 \text { in Dia ABS } \\
\text { Pipe plus end } \\
\text { caps }\end{array}$ & Don Legare & 3 ea approx 80 feet long & $73 \mathrm{ft}$ & 28 in dia & & 502 & low & & & crane \\
\hline 26 & $\begin{array}{l}\text { LLCE Long Lift } \\
\text { Beam }\end{array}$ & Don Legare & $\begin{array}{l}30 \text { in I-beam, approx } 72 \text { feet long } \\
\text { (store contaminated) }\end{array}$ & $71 \mathrm{ft}$ & 24 in & 13 in & 141 & moderate & painted & moderate & crane \\
\hline 27 & $\begin{array}{l}\text { 106-C Pit A } \\
\text { Work Platform } \\
\text { Large }\end{array}$ & $\begin{array}{l}\text { W-320 } \\
\text { (Project W- } \\
320 \text { is } \\
\text { complete. } \\
\text { Excess } \\
\text { Equip) }\end{array}$ & $\begin{array}{l}\text { WGS-XVV-375234 S/N } 189296 \\
\text { (store contaminated) }\end{array}$ & $228 \mathrm{in}$ & $112 \mathrm{in}$ & 69 in & 177 & low & & & fork truck \\
\hline 28 & $\begin{array}{l}\text { 106-C Pit A } \\
\text { Work Platform } \\
\text { Medium }\end{array}$ & W-320 & $\begin{array}{l}\text { WGS-XVV-375234 S/N } 189289 \\
\text { (store contaminated) }\end{array}$ & 144 in & 89 in & 42 in & 89 & low & & & fork truck \\
\hline 29 & $\begin{array}{l}\text { 106-C Pit A } \\
\text { Work Platform } \\
\text { Small }\end{array}$ & W-320 & $\begin{array}{l}\text { WGS-XVV-378234 S/N } 189049 \\
\text { (store contaminated) }\end{array}$ & $161 \mathrm{in}$ & 168 in & 24 in & 187 & low & & & fork truck \\
\hline 30 & $\begin{array}{l}34 \text { in Dia Pipe } \\
\text { with Flange }\end{array}$ & W-320 & & 130 in & 43 in dia & & 39 & moderate & rust & low & fork truck \\
\hline 31 & 72 in Dia Culvert & $W-320$ & & 99 in & 72 in dia & & 49 & low & & & fork truck \\
\hline 32 & Tower & W-320 & $\begin{array}{l}\text { Approx } 50 \mathrm{ft} \mathrm{high} \\
\text { (store contaminated) }\end{array}$ & $42 \mathrm{ft}$ & 138 in & 100 in & 477 & moderate & painted & moderate & crane \\
\hline 33 & $\begin{array}{l}\text { Rectangular } \\
\text { Container }\end{array}$ & W-320 & $\begin{array}{l}\mathrm{H}-2-820736, \mathrm{~S} N \mathrm{~N} 189254 \\
\text { (store contaminated) }\end{array}$ & 227 in & 89 in & 137 in & 140 & low & - & & fork truck \\
\hline 34 & $\begin{array}{l}\text { Rectangular } \\
\text { Container } \\
42 \text { in } \\
\text { Flex/receiver } \\
\text { Cartridge } 2 \text { each } \\
\end{array}$ & W-320 & $\begin{array}{l}\text { H-2-79352/H-2-73359 } \\
\text { (numbers on only one) } \\
\text { (store contaminated) } \\
\text { S/N's } 189203 / 4 \text { ) }\end{array}$ & $\begin{array}{c}106 \text { in } \\
?\end{array}$ & 146 in & 114 in & 215 & low & & & fork truck \\
\hline
\end{tabular}




\begin{tabular}{|c|c|c|c|c|c|c|c|c|c|c|c|}
\hline Item & Description & Belongs to & Comment & Lngth & Width & Ht & Area $\mathrm{ft}^{2}$ & $\begin{array}{l}\text { Importance of } \\
\text { Storage } \\
\end{array}$ & $\begin{array}{l}\text { Material } \\
\text { Concerns }\end{array}$ & $\begin{array}{c}\text { Replace } \\
\text { Cost }\end{array}$ & $\begin{array}{c}\text { Handle } \\
\text { With }\end{array}$ \\
\hline 35 & $\begin{array}{l}\text { Rectangular } \\
\text { Container } \\
\text { Sluicing Pit AY- } \\
\text { O2B } \\
\end{array}$ & W-320 & $\begin{array}{l}\text { H-2-820735 } \\
\text { (store contaminated) }\end{array}$ & 169 in & 162 in & 152 in & 190 & low & & & fork truck \\
\hline 36 & Short Tower & W-320 & (approx $10 \mathrm{ft}$ high) & 233 in & $150 \mathrm{in}$ & $\begin{array}{l}135.5 \\
\text { in }\end{array}$ & 243 & excess & & & \\
\hline 37 & $\begin{array}{l}\text { Moveable, } \\
\text { Elevated Drum }\end{array}$ & W-320 & (approx $15 \mathrm{ft} \mathrm{high)}$ & 112 in & 99 in & $\begin{array}{l}164.5 \\
\text { in }\end{array}$ & 76 & excess & & & \\
\hline 38 & $\begin{array}{l}\text { Rectangular } \\
\text { Container } \\
\text { Heel Pit CR-06B } \\
\text { W-320 }\end{array}$ & $W-320$ & $\begin{array}{l}\mathrm{H}-2-820737 \mathrm{~S} / \mathrm{N} 189205 \\
\text { (store contaminated) }\end{array}$ & 150 in & $120 \mathrm{in}$ & 95.5 in & 125 & low & & & fork truck \\
\hline 39 & $\begin{array}{l}\text { Rectangular } \\
\text { Container } \\
\text { Bag Assembly }\end{array}$ & $W-320$ & $\begin{array}{l}\text { H-2-79297 } \\
\text { (store contaminated) }\end{array}$ & 72 in & $49 \mathrm{in}$ & $52 \mathrm{in}$ & 24 & low & $\cdot$ & & fork truck \\
\hline 40 & $\begin{array}{l}\text { Rectangular } \\
\text { Container } \\
\text { Rectangular }\end{array}$ & $W-320$ & $\begin{array}{l}\text { S/N } 189288 \\
\text { (store contaminated) }\end{array}$ & 110.5 in & 82 in & 53 in & 63 & low & & & Crane \\
\hline 41 & $\begin{array}{l}\text { Container } 42 \text { in } \\
\text { Prototype Leak } \\
\text { Containment Bag }\end{array}$ & $W-320$ & $\begin{array}{l}\text { H-2-79362 } \\
\text { (store contaminated) }\end{array}$ & 111 in & $82 \mathrm{in}$ & 53 in & 63 & low & & & Crane \\
\hline 42 & $\begin{array}{l}\text { Railings (3) and } \\
\text { Plates (2) }\end{array}$ & $W-320$ & (store contaminated) & $170 \mathrm{in}$ & 127 in & $24 \mathrm{in}$ & 1.50 & low & $\cdot$ & & Fork truck \\
\hline 43 & $\begin{array}{l}\text { LLCE Receiver } \\
\text { Trailer }\end{array}$ & TWRS/CPO & $\begin{array}{l}\mathrm{HO}-64-4283 \\
\text { (store contaminated) }\end{array}$ & $83 \mathrm{ft}$ & 154 in & 172 in & 1,059 & moderate & $\begin{array}{l}\text { hyd \& } \\
\text { elec equ }\end{array}$ & enormous & $\begin{array}{l}\text { semi } \\
\text { tractor }\end{array}$ \\
\hline 44 & $\begin{array}{l}\text { LLCE } \\
\text { Transportationr } \\
\text { Trailer } \\
\end{array}$ & TWRS/CPO & $\begin{array}{l}\text { HO- } 64-4280 \\
\text { (store contaminated) }\end{array}$ & $\begin{array}{c}77 \mathrm{ft} \\
. \\
\end{array}$ & 154 in & $\begin{array}{l}162.5 \\
\text { in }\end{array}$ & 982 & moderate & $\begin{array}{l}\text { hyd \& } \\
\text { elec equ }\end{array}$ & enormous & $\begin{array}{l}\text { semi } \\
\text { tractor }\end{array}$ \\
\hline 45 & $\begin{array}{l}\text { Conex Box } \\
210526-0\end{array}$ & TWRS/CPO & $210526-0$ & 238 in & 97 in & $\begin{array}{l}104.5 \\
\text { in }\end{array}$ & 160 & negligible & & & fork truck \\
\hline
\end{tabular}




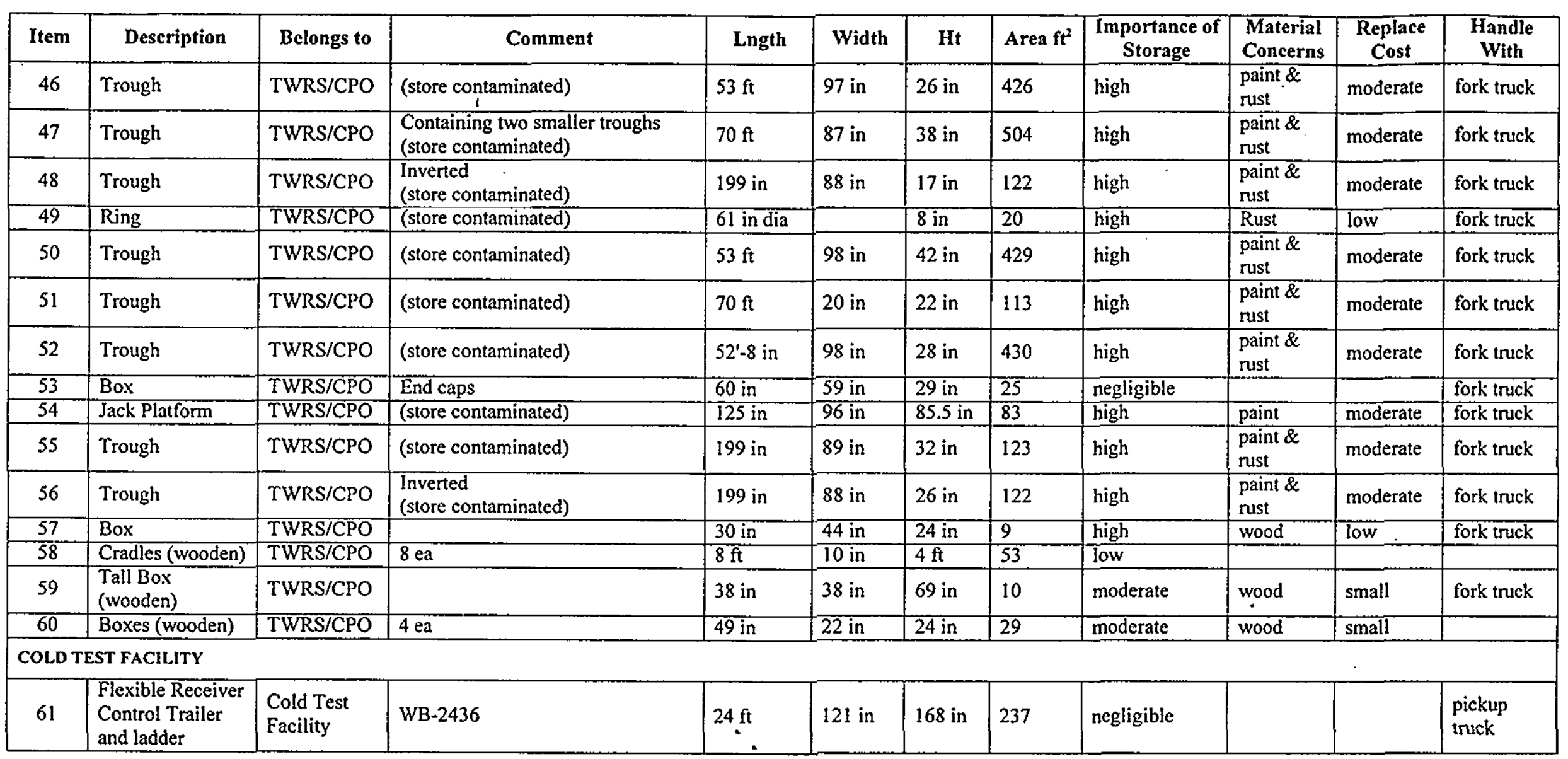




\begin{tabular}{|c|c|c|c|c|c|c|c|c|c|c|c|}
\hline Item & Description & Belongs to & Comment & Lngth & Width & Ht & Area $\mathrm{ft}^{2}$ & $\begin{array}{c}\text { Importance of } \\
\text { Storage }\end{array}$ & $\begin{array}{l}\text { Material } \\
\text { Concerns }\end{array}$ & $\begin{array}{c}\text { Replace } \\
\text { Cost }\end{array}$ & $\begin{array}{c}\text { Handle } \\
\text { With }\end{array}$ \\
\hline 63 & Lunch Room & $\mathrm{W}-15 \mathrm{l} / 211$ & MO 667 PNL 622R & $34 \mathrm{ft}$ & $10 \mathrm{ft}$ & 127 in & 310 & negligible & & & $\begin{array}{l}\text { pickup } \\
\text { truck }\end{array}$ \\
\hline 68 & $\begin{array}{l}\text { 42-Inch Flexible } \\
\text { Receiver }\end{array}$ & $W-151 / 211$ & (store contaminated) & 119 in & 76 in & 53 in & 62 & high & Hydraulic & moderate & fork truck \\
\hline 69 & $\begin{array}{l}\text { Flexible Receiver } \\
\text { Dispenser }\end{array}$ & W-151/211 & (store contaminated) & 95 in & 95 in & 98 in & 63 & negligible & & & fork truck \\
\hline 75 & $\begin{array}{l}\text { Gamma Assay } \\
\text { System } \\
\text { Controller } \\
\end{array}$ & $W-151 / 211$ & $\begin{array}{l}\text { with air conditioner and pile of } \\
\text { coax on top } \\
\text { (store contaminated) }\end{array}$ & 36 in & $23 \mathrm{in}$ & 35 in & 6 & high & $\begin{array}{l}\text { Electrical } \\
\& \text { instrum }\end{array}$ & high & \\
\hline 76 & $\begin{array}{l}\text { 42-Inch } \\
\text { Secondary } \\
\text { Bagger }\end{array}$ & $W-151 / 211$ & $\begin{array}{l}\text { (Large) } \\
\text { (store contaminated) }\end{array}$ & 93 in & 65 in & 37 in & 42 & high & Hydraulic & moderate & fork truck \\
\hline 77 & $\begin{array}{l}\text { 4-to-6 Inch } \\
\text { Bagger Assy }\end{array}$ & W-151/211 & $\begin{array}{l}\text { (Small) } \\
\text { (store contaminated) }\end{array}$ & 52 in & 32 in & 37 in & 12 & high & hyraulic & moderate & fork truck \\
\hline 78 & $\begin{array}{l}\text { Flexible Receiver } \\
\text { Fingers }\end{array}$ & $\mathrm{W}-151 / 211$ & $\begin{array}{l}2 \text { sets, nested } \\
\text { (store contaminated) }\end{array}$ & 78 in dia & & 75 in & 33 & negligible & & & fork truck \\
\hline 83 & $\begin{array}{l}\text { Tool Boxes } \\
\text { containing wire } \\
(3 \mathrm{ea})\end{array}$ & $\mathrm{W}-151 / 211$ & size of each & 48 in & 24 in & $19 \mathrm{in}$ & 32 & moderate & $\begin{array}{l}\text { painted } \\
\text { w/ wire }\end{array}$ & small & fork truck \\
\hline 84 & Wooden Box & W-151/211 & & 47 in & 24 in & 28 in & 8 & high & wood & small & fork truck \\
\hline 88 & $\begin{array}{l}\text { Distribution } \\
\text { Panel } \\
\end{array}$ & $\begin{array}{l}\text { Cold Test } \\
\text { Facility }\end{array}$ & $200 \mathrm{~A}, 480 \mathrm{~V}+$ & 89 in & $14 \mathrm{in}$ & 68 in & 9 & negligible & $\cdot$ & & \\
\hline 89 & $\begin{array}{l}\text { Storage } \\
\text { Container } \\
\text { (Empty) }\end{array}$ & $\begin{array}{l}\text { Cold Test } \\
\text { Facility }\end{array}$ & (store contaminated) & 134 in & 133 in & 159 in & 124 & low & & & crane \\
\hline 90 & Platform & W-211 & $\begin{array}{l}\text { H-2-824707 REV 1 } \\
\text { (store contaminated) }\end{array}$ & 170 in & $95 \mathrm{in}$ & 20 in & 112 & moderate & painted & high & fork truck \\
\hline
\end{tabular}




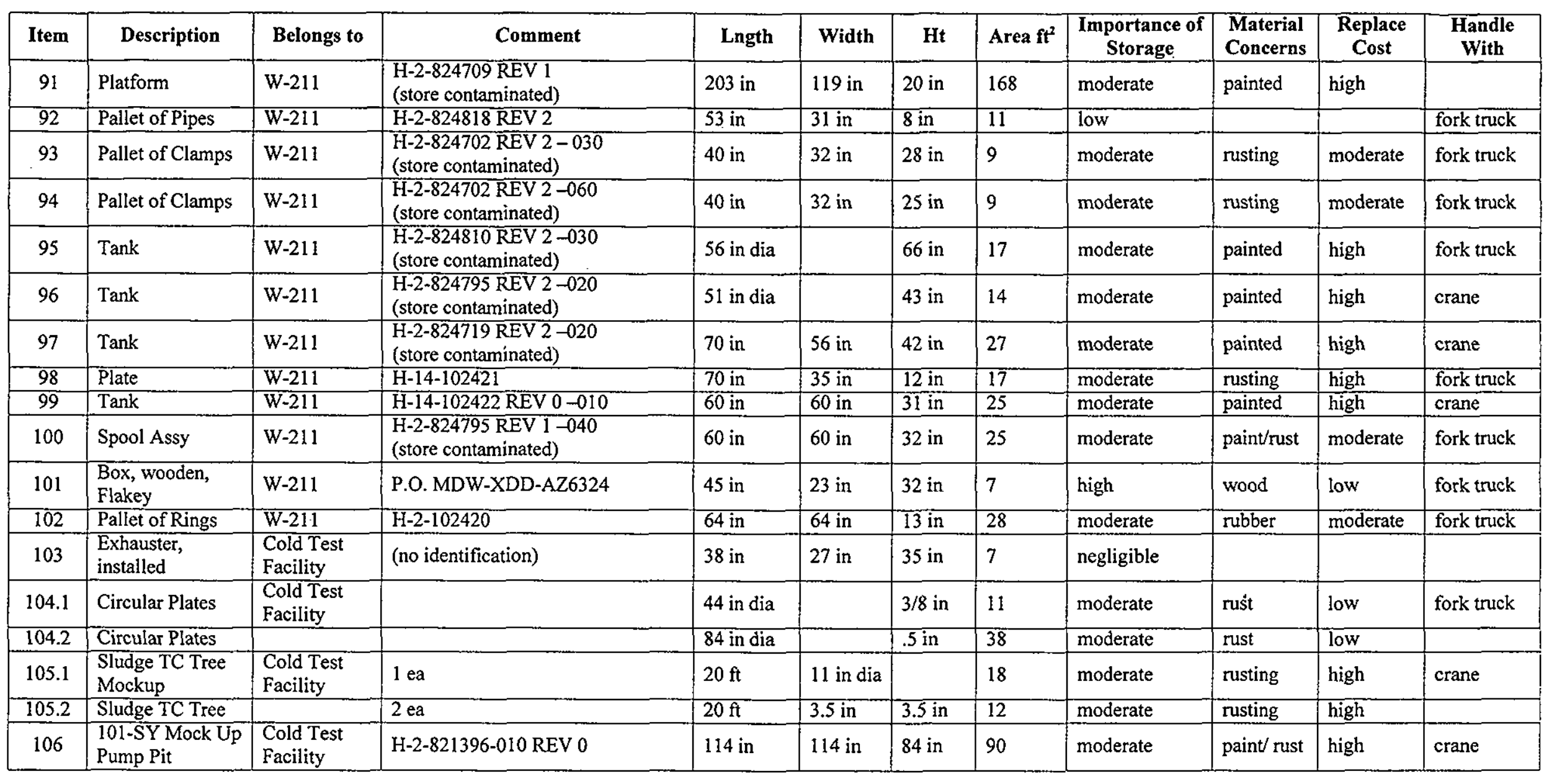




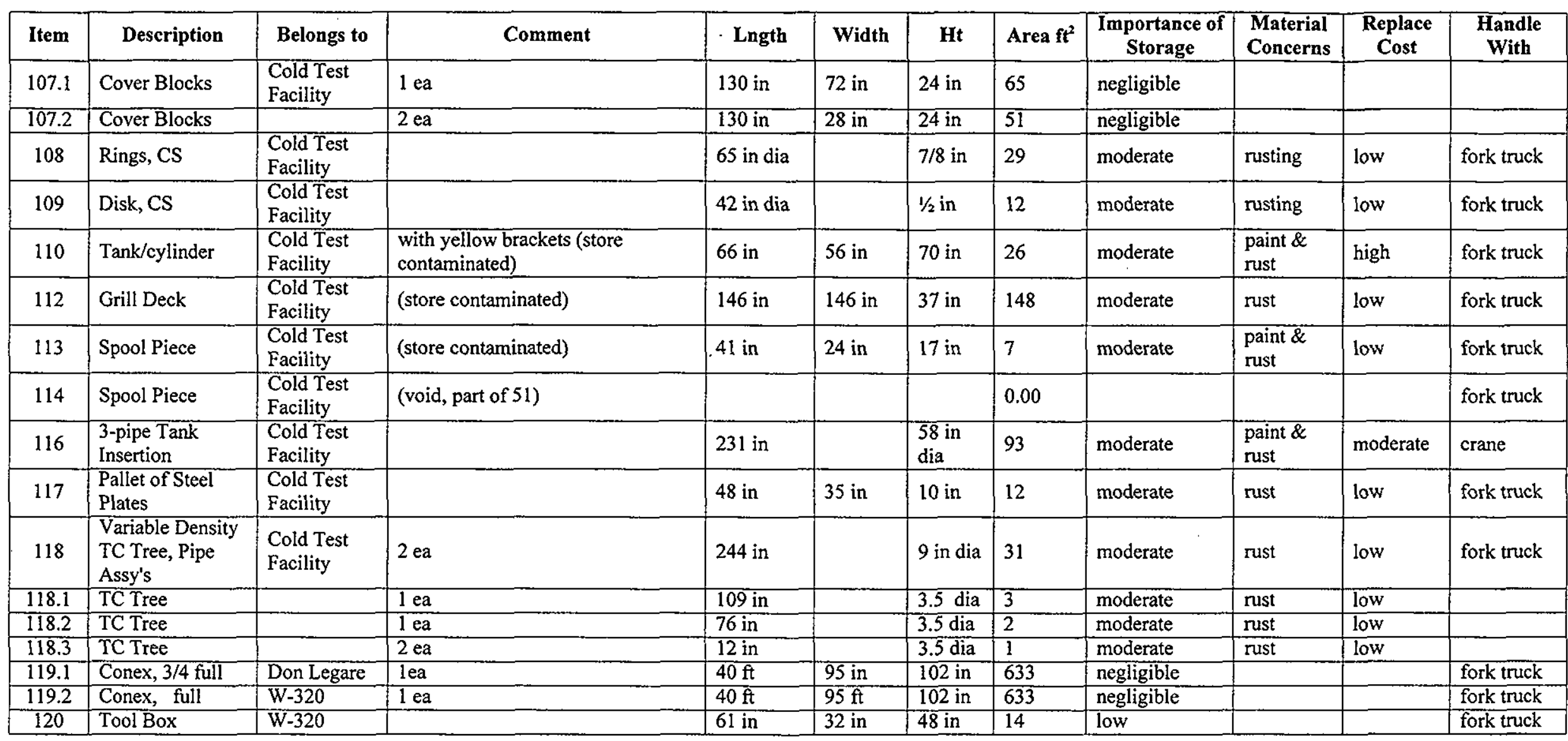




\begin{tabular}{|c|c|c|c|c|c|c|c|c|c|c|c|}
\hline Item & Description & Belongs to & Comment & Lngth & Width & $\mathbf{H t}$ & Area $\mathrm{ft}^{2}$ & $\begin{array}{c}\text { Importance of } \\
\text { Storage }\end{array}$ & $\begin{array}{l}\text { Material } \\
\text { Concerns }\end{array}$ & $\begin{array}{c}\text { Replace } \\
\text { Cost }\end{array}$ & $\begin{array}{c}\text { Handle } \\
\text { With }\end{array}$ \\
\hline 121 & $\begin{array}{l}\text { Yoke Handled } \\
\text { Vessel, Mockup } \\
\text { Test Pump }\end{array}$ & $\begin{array}{l}\text { Cold Test } \\
\text { Facility }\end{array}$ & (store contaminated) & 100 in & & $25 \mathrm{dia}$ & 17 & moderate & $\begin{array}{l}\text { paint \& } \\
\text { rust }\end{array}$ & moderate & crane \\
\hline 122 & Platform & $\begin{array}{l}\text { Cold Test } \\
\text { Facility }\end{array}$ & (store contaminated) & 145 in & 64 in & 22 in & 64 & moderate & paint & moderate & fork truck \\
\hline 123 & Bellows & $\begin{array}{l}\text { Cold Test } \\
\text { Facility }\end{array}$ & (store contaminated) & 38 in dia & & 10 in & 10 & moderate & rust & low & \\
\hline 124 & $\begin{array}{l}\text { White, } \\
\text { Horizontal } \\
\text { Cylinder, Spool } \\
\text { Piece }\end{array}$ & $\begin{array}{l}\text { Cold Test } \\
\text { Facility }\end{array}$ & (store contaminated) & 141 in & 48 in & 41 in & 47 & moderate & paint & low & crane \\
\hline 125 & $\begin{array}{l}\text { Pot-bellied } \\
\text { Cylinder, white, } \\
\text { (Proj 151) }\end{array}$ & $\begin{array}{l}\text { Cold Test } \\
\text { Facility }\end{array}$ & (store contaminated) & 68 in & 60 in & $41 \mathrm{in}$ & 28 & moderate & $\begin{array}{l}410 \\
\text { stainless }\end{array}$ & moderate & crane \\
\hline 126 & Pipe Attachments & $\begin{array}{l}\text { Cold Test } \\
\text { Facility }\end{array}$ & $6 \mathrm{ea}$ & 41 in dia & & 10 in & 70 & low & & & fork truck \\
\hline 127 & $\begin{array}{l}\text { Power Outlet } \\
(\mathrm{elec})\end{array}$ & $\begin{array}{l}\text { Cold Test } \\
\text { Facility }\end{array}$ & not hooked up & 50 in & $30 \mathrm{in}$ & 38 in & 10 & low & & & \\
\hline 128 & $\begin{array}{l}\text { Box with Foot } \\
\text { Clamp }\end{array}$ & $\begin{array}{l}\text { Cold Test } \\
\text { Facility }\end{array}$ & (over by rect cont.) & 29 in & 45 in & $24 \mathrm{in}$ & 9. & excess & & & \\
\hline 129 & Steel Pipe & $\begin{array}{l}\text { Cold Test } \\
\text { Facility }\end{array}$ & by RR tracks, near conexes & 95 in & & $13 \mathrm{dia}$ & 9 & low & & & fork truck \\
\hline 130 & $\begin{array}{l}\text { SS Cylindrical } \\
\text { Shell }\end{array}$ & $\begin{array}{l}\text { Cold Test } \\
\text { Facility } \\
\end{array}$ & $\begin{array}{l}\text { near bellows } \\
\text { (store contaminated) }\end{array}$ & 37 in dia & & 10 in & 10 & & • & & crane \\
\hline \multicolumn{12}{|c|}{ EAST OF 241-AP EAST OF 241-AP } \\
\hline 131 & Burial Containers & W-211 & 3 ea & $73 \mathrm{ft}$ & 96 in & $61 \mathrm{in}$ & 1,752 & low & & & crane \\
\hline \multicolumn{12}{|c|}{ BY FLUOR DANIEL NW } \\
\hline 134 & $\begin{array}{l}\text { AZ Removal } \\
\text { Platform }\end{array}$ & W-151/211 & $\begin{array}{l}\text { H-2-97223 } \\
\text { (store contaminated) }\end{array}$ & 126 in & 145 in & 15 in & 126 & low & & & fork truck \\
\hline
\end{tabular}

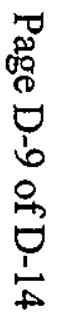




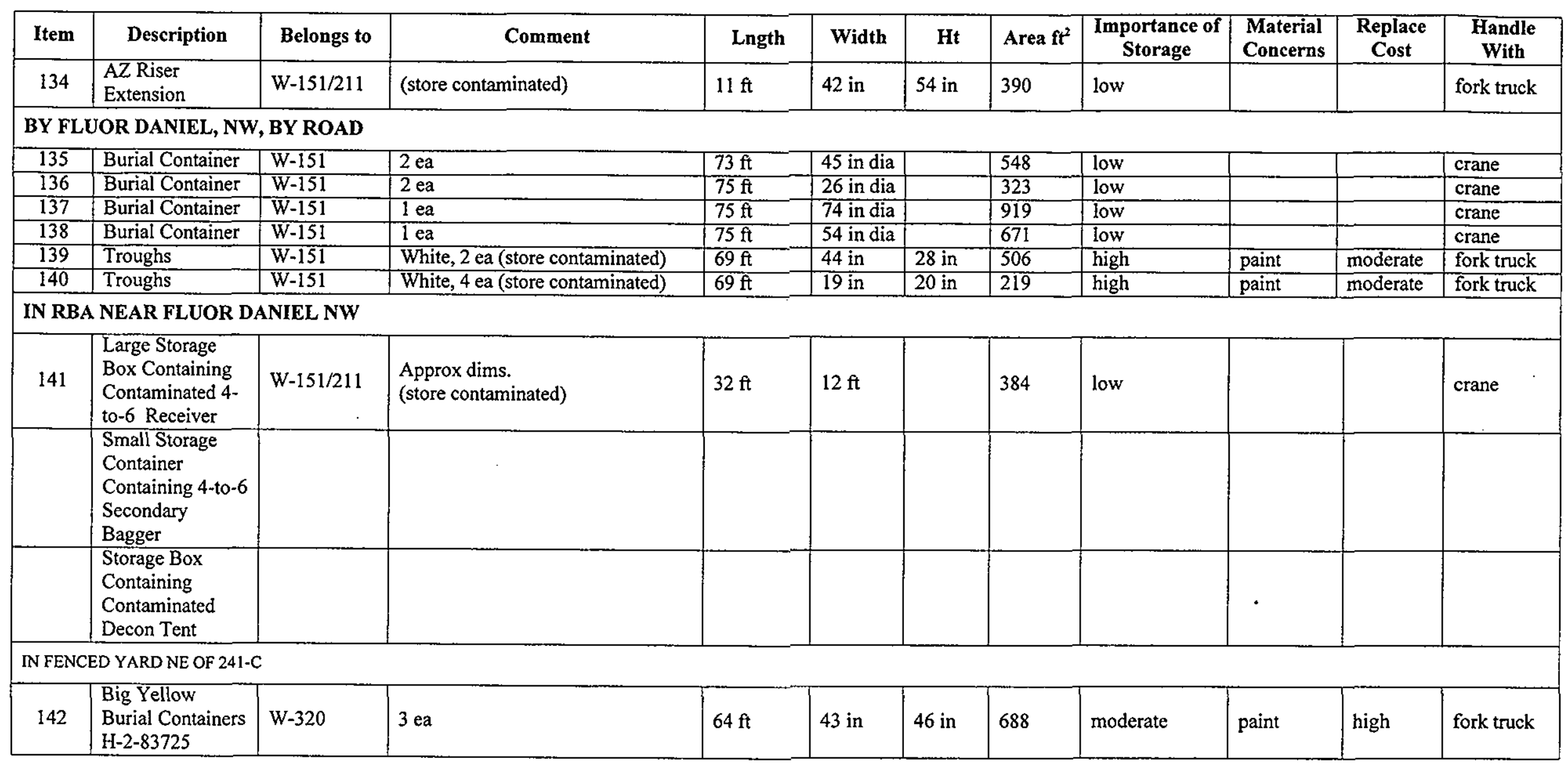




\begin{tabular}{|c|c|c|c|c|c|c|c|c|c|c|c|}
\hline Item & Description & Belongs to & Comment & Lngth & Width & $\mathbf{H t}$ & Area $\mathrm{ft}^{2}$ & $\begin{array}{l}\text { Importance of } \\
\text { Storage }\end{array}$ & $\begin{array}{l}\text { Material } \\
\text { Concerns }\end{array}$ & $\begin{array}{c}\text { Replace } \\
\text { Cost }\end{array}$ & $\begin{array}{c}\text { Handle } \\
\text { With }\end{array}$ \\
\hline 143 & $\begin{array}{l}\text { Cover for burial } \\
\text { container } \\
\mathrm{H}-2-83722\end{array}$ & W-320 & 1 ea & 66 in & 49 in & 8.5 in & 22 & moderate & paint & low & fork truck \\
\hline 144 & $\begin{array}{l}\text { Pallets of } \\
\text { Brackets } \\
\mathrm{H}-2-82073 \\
\end{array}$ & $W-320$ & $\begin{array}{l}3 \text { ea } \\
\text { (store contaminated) }\end{array}$ & $40 \mathrm{in}$ & 32 in & & 27 & moderate & paint & low & fork truck \\
\hline 145 & $\begin{array}{l}\text { Yoke H-2- } \\
820741 \\
\end{array}$ & W-320 & $\begin{array}{l}\text { I ea } \\
\text { (store contaminated) }\end{array}$ & 48 in & 34 in & $11 \mathrm{in}$ & 11 & high & $\begin{array}{l}\text { paint \& } \\
\text { rust }\end{array}$ & high & crane \\
\hline 146 & $\begin{array}{l}\text { Cradles, on } 3 \\
\text { pallets } \\
\text { H-2-83725 }\end{array}$ & W-320 & $\begin{array}{l}21 \text { ea } \\
\text { (store contaminated) }\end{array}$ & 52 in & 14 in & 13 in & 36 & moderate & paint & moderate & fork truck \\
\hline 147 & $\begin{array}{l}\text { Platform } \\
\text { H2-820730 }\end{array}$ & W-320 & 1 ea & $17 \mathrm{ft}$ & $14 \mathrm{ft}$ & $12 \mathrm{in}$ & 23 & moderate & paint & moderate & fork truck \\
\hline \multirow[t]{2}{*}{148} & $\begin{array}{l}\text { ??Agitator, Heel } \\
\text { Jet, Heel Pit?? }\end{array}$ & W-320 & & & & & & $\begin{array}{l}\text { (not LLCE } \\
\text { stuff) }\end{array}$ & & & . \\
\hline & Total LLCE & & & & & 21,000 & & & & & \\
\hline
\end{tabular}


EQUIPMENT NOT IMPORTANT TO LLCE SYSTEM

\begin{tabular}{|c|c|c|c|c|c|c|c|c|c|c|c|c|}
\hline Item & Description & Comment & Lngth & Width & Ht & $\begin{array}{c}\text { Area } \\
\mathrm{ft}^{2}\end{array}$ & $\begin{array}{l}\text { Importance } \\
\text { of Storage }\end{array}$ & $\begin{array}{l}\text { Material } \\
\text { Concerns }\end{array}$ & $\begin{array}{c}\text { Type (heat, } \\
\text { weather) }\end{array}$ & $\begin{array}{c}\text { Service } \\
\text { space }\end{array}$ & $\begin{array}{l}\text { Replace } \\
\text { cost }\end{array}$ & $\begin{array}{c}\text { Handle } \\
\text { with }\end{array}$ \\
\hline 3 & Dunnage & $\begin{array}{l}2 \text { W.F. Beams } 2 \text { I- } \\
\text { beams } 4 \text { brackets } \\
2 \text { Channels }\end{array}$ & $\begin{array}{l}24 \mathrm{ft} \\
18 \mathrm{ft} \\
22 \mathrm{in} \\
20 \mathrm{ft}\end{array}$ & $\begin{array}{l}95 / 8 \text { in } \\
41 / 2 \text { in } \\
10 \mathrm{in} \\
5 \mathrm{in}\end{array}$ & $\begin{array}{l}8 \mathrm{in} \\
123 / 8 \text { in } \\
10 \mathrm{in} \\
11 / 2 \mathrm{in}\end{array}$ & 75 & Low & & & & & fork truck \\
\hline 4 & $\begin{array}{l}\text { Semi circular } \\
\text { Casing Sections }\end{array}$ & $\begin{array}{l}\text { Approx } 5 \mathrm{ft} \text { long } \times 2 \mathrm{ft} \\
\text { high } \\
92 \text { in } 5 \text { piles } \\
\text { (store contaminated) }\end{array}$ & 51 in & 100 in & 30 in & 177 & Low & & & & & fork truck \\
\hline 6 & Rocking Shapes & $\begin{array}{l}2 \text { ea } \\
\text { (store contaminated) }\end{array}$ & 29 in & 24 in & 22 in & 10 & Low & & & & & \\
\hline 8 & $\begin{array}{l}\text { In-tank } \\
\text { Insertion }\end{array}$ & $\begin{array}{l}\text { Pipe welded to big } \\
\text { plate. } 65 / 8 \text { in dia } \\
\text { pipe }\end{array}$ & $19 \mathrm{ft}$ & 52 in & 52 in & 82 & Low & & & & & crane \\
\hline 10 & $\begin{array}{l}\text { RISER/DRYW } \\
\text { ELL } \\
\text { MAPPING } \\
\text { POSITIONER }\end{array}$ & $\begin{array}{l}\text { WHC-S-0099, Model } \\
1354 \text {, Acme Machine } \\
\text { Works, Spokane, } \\
\text { P.O. WDW-XVV. } \\
3274381354\end{array}$ & 77 in & 70 in & $9 \mathrm{ft}$ & 37 & $\begin{array}{l}\text { to be } \\
\text { excessed }\end{array}$ & & & & & \\
\hline 11 & Pallet of Panels & & 80 in & 67 in & $20 \mathrm{in}$ & 37 & Moderate & $\begin{array}{l}\text { paint \& } \\
\text { rust }\end{array}$ & roof & no & low & fork truck \\
\hline 13 & Impact Limiter & $\begin{array}{l}2 \text { semi-circular } \\
\text { sections } \\
\text { (store contaminated) }\end{array}$ & 76 in & 38 in & 49 in & 40 & Low & & & . & & \\
\hline 15 & Spool (empty) & & 22 in dia & 10 in & & 2 & Low & & & & & \\
\hline 16 & $\begin{array}{l}\text { Plugs, Valve } \\
\text { Handles ( } 2 \text { ea), } \\
\text { Welded Bracket } \\
\text { on pallet }\end{array}$ & $\begin{array}{l}\mathrm{H}-2-78985 \\
40 \times 47 \text { pallet }\end{array}$ & 68 in & $\begin{array}{l}4 \text { in dia } \\
9 \text { in dia } \\
\text { flange }\end{array}$ & & 13 & Low & & & & & fork truck \\
\hline
\end{tabular}

11

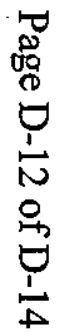




\begin{tabular}{|c|c|c|c|c|c|c|c|c|c|c|c|c|}
\hline Item & Description & Comment & Lngth & Width & $\mathbf{H t}$ & $\begin{array}{c}\text { Area } \\
\mathrm{ft}^{2}\end{array}$ & $\begin{array}{l}\text { Importance } \\
\text { of Storage }\end{array}$ & $\begin{array}{l}\text { Material } \\
\text { Concerns }\end{array}$ & $\begin{array}{c}\text { Type (heat, } \\
\text { weather) }\end{array}$ & $\begin{array}{l}\text { Service } \\
\text { space }\end{array}$ & $\begin{array}{c}\text { Replace } \\
\text { cost }\end{array}$ & $\begin{array}{c}\text { Handle } \\
\text { with }\end{array}$ \\
\hline 19 & $\begin{array}{l}\text { In-tank } \\
\text { temperature } \\
\text { probe }\end{array}$ & $\mathrm{H}-14-100656-010$ & $57.5 \mathrm{ft}$ & 28 in & 21 in & 132 & Low & & & & & crane \\
\hline 21 & Stair/porch & & 103 in & 94 in & 72 in & 67 & Low & & & & & fork truck \\
\hline 24 & $\begin{array}{l}\text { Empty } \\
\text { Hoffman Box }\end{array}$ & . & 30 in & 36 in & 12 in & 8 & Excess & & & & & \\
\hline \multicolumn{13}{|c|}{ COLD TEST FACILITY } \\
\hline 62 & $\begin{array}{l}\text { Stair for FRC } \\
\text { Trailer }\end{array}$ & & 128 in & 48 in & 87 in & 43 & Low & & & & & fork truck \\
\hline 64 & Chairs (4 ea) & pile, stacked & $2 \mathrm{ft}$ & $2 \mathrm{ft}$ & $3 \mathrm{ft}$ & 3 & Low & & & & & \\
\hline 65 & $\begin{array}{l}\text { Trash Can } \\
\text { Stand }\end{array}$ & Kaiser Hanford Co. & 32 in & 24 in & 60 in & 5 & Low & & & & & \\
\hline 66 & Wash Rack & & 49 in & 24 in & 57 in & 8 & Low & & & & & \\
\hline 67 & Picnic Table & & 96 in & 59 in & 33 in & 39 & Low & & & & & \\
\hline 70 & $\begin{array}{l}\text { Trash Can (3 } \\
\text { ea) }\end{array}$ & size of each & 19 in in & 19 in & 30 in & 8 & Negligible & & & & & \\
\hline 72 & $\begin{array}{l}\text { Personnel } \\
\text { Traffic Rope } \\
\text { Stands }\end{array}$ & 19 each & 17 in & 17 in & 42 in & 38 & Negligible & & & & & \\
\hline 73 & $\begin{array}{l}\text { T-posts (approx } \\
\text { one dozen) }\end{array}$ & whole pile & 64 in & 6 in & 8 in & 3 & Negligible & & & • & & \\
\hline 80 & $\begin{array}{l}\text { Stair/porch for } \\
\text { trailer } 2 \text { ea }\end{array}$ & size of each & 92 in & 48 in & 73 in & 61 & Low & & & & & fork truck \\
\hline 82 & Empty Spool & & 40 in dia & & $32 \mathrm{in}$ & 9 & Low & & & & & \\
\hline 85 & $\begin{array}{l}\text { Traffic } \\
\text { Barricades ( } 2 \\
\text { ea) }\end{array}$ & Pile & $45 \mathrm{in}$ & 24 in & 6 in & 8 & Negligible & & . & & & \\
\hline
\end{tabular}

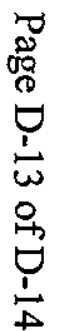




\begin{tabular}{|c|c|c|c|c|c|c|c|c|c|c|c|c|}
\hline Item & Description & Comment & Lngth & Width & $\mathbf{H t}$ & $\begin{array}{c}\text { Area } \\
\mathrm{ft}^{2}\end{array}$ & $\begin{array}{l}\text { Importance } \\
\text { of Storage }\end{array}$ & $\begin{array}{l}\text { Material } \\
\text { Concerns }\end{array}$ & $\begin{array}{c}\text { Type (heat, } \\
\text { weather) }\end{array}$ & $\begin{array}{c}\text { Service } \\
\text { space }\end{array}$ & $\begin{array}{c}\text { Replace } \\
\text { cost }\end{array}$ & $\begin{array}{c}\text { Handle } \\
\text { with }\end{array}$ \\
\hline 86 & $\begin{array}{l}\text { Miscellaneous } \\
\text { Scaffolding }\end{array}$ & Pile & 10 in & 6 in & 8 in & 1 & Low & & & & & \\
\hline 87 & $\begin{array}{l}\text { Extension } \\
\text { Ladder }\end{array}$ & & 148 in & 17 in & 6 in & 17 & Moderate & no & roof \& walls & no & small & \\
\hline 111 & Stair/porch & & 100 in & 51 in & 84 in & 35 & Low & & & & & fork truck \\
\hline 112 & Grill Deck & (store contaminated) & 146 in & 146 in & 37 in & 148 & Moderate & rust & tarp & no & low & crane \\
\hline 115 & Deck/Porch & & 72 in & 45 in & 62 in & 23 & Low & & & & & fork truck \\
\hline \multicolumn{3}{|c|}{ TOTAL FOR APPENDIX D } & & & & 2,200 & & & & & & \\
\hline
\end{tabular}

(McKinney input) 